Momentum in stock market returns:

Implications for risk premia on foreign currencies

Thomas Nitschka

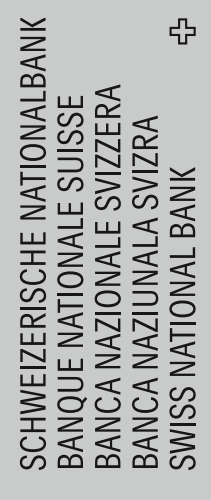


The views expressed in this paper are those of the author(s) and do not necessarily represent those of the Swiss National Bank. Working Papers describe research in progress. Their aim is to elicit comments and to further debate.

\section{Copyright $\odot$}

The Swiss National Bank (SNB) respects all third-party rights, in particular rights relating to works protected by copyright (information or data, wordings and depictions, to the extent that these are of an individual character). SNB publications containing a reference to a copyright ( $\odot$ Swiss National Bank/SNB, Zurich/year, or similar) may, under copyright law, only be used (reproduced, used via the internet, etc.) for non-commercial purposes and provided that the source is mentioned. Their use for commercial purposes is only permitted with the prior express consent of the SNB.

General information and data published without reference to a copyright may be used without mentioning the source.

To the extent that the information and data clearly derive from outside sources, the users of such information and data are obliged to respect any existing copyrights and to obtain the right of use from the relevant outside source themselves.

\section{Limitation of liability}

The SNB accepts no responsibility for any information it provides. Under no circumstances will it accept any liability for losses or damage which may result from the use of such information. This limitation of liability applies, in particular, to the topicality, accuracy, validity and availability of the information.

ISSN 1660-7716 (printed version)

ISSN 1660-7724 (online version)

๑ 2010 by Swiss National Bank, Börsenstrasse 15, P.0. Box, CH-8022 Zurich 


\title{
Momentum in stock market returns: Implications for risk premia on foreign currencies
}

\author{
Thomas Nitschka ${ }^{1}$
}

Swiss National Bank

March 21, 2010

\begin{abstract}
Momentum in foreign stock market returns is exploitable as signal of currency excess returns. Past stock market winner currencies offer higher returns than past stock market loser currencies. This finding is unrelated to interest rate differentials. Funding liquidity risk explains the time series variation in foreign stock market momentum sorted currency portfolio returns. Their cross-sectional dispersion is hardly rationalized by systematic risk factors in contrast to forward discount and currency momentum sorted currency portfolios. This latter finding reflects that fundamentals driving stock market momentum based currency portfolio returns are not related to recently proposed currency risk factors in the cross-section.
\end{abstract}

JEL: F31, F37, G15

Keywords: currency returns, expected return news, intrinsic value, momentum, risk premia, stock market returns

\footnotetext{
${ }^{1}$ E-mail: thomas.nitschka@snb.ch, Web: http://sites.google.com/site/tnitschka Postal address: Swiss National Bank, Financial Stability Unit, Bundesplatz 1, 3003 Berne, Switzerland. This paper benefitted substantially from comments by an anonymous referee of the Swiss National Bank working paper series and Mahmoud Botshekan, my discussant, as well as other participants in the $13^{\text {th }}$ SGF conference. Substantial parts of this research have been conducted during my time as post-doctoral researcher at the University of Zurich. The views expressed in this paper are those of the author and do not necessarily reflect the stance of the Swiss National Bank. The paper supersedes "Momentum in stock market returns, risk premia on foreign currencies and international financial integration", IEW working paper 405, University of Zurich, March 2009. Any errors and omissions are my own.
} 


\section{Introduction}

High stock returns tend to predict high stock returns in the near future. This phenomenon, known as momentum, is not only pervasive at the firm-level (Jegadeesh and Titman (1993), Rouwenhorst (1998)) but also present in country stock market returns (Asness, Liew and Stevens (1997), Bhojraj and Swaminathan (2006)). If we are willing to accept a stock market return as proxy for systematic risk, as usually done in empirical tests of the Sharpe (1964) and Lintner (1965) capital asset pricing model (CAPM), then this latter finding suggests that times of high systematic risks also signal risky times in the short run. Hence, past high (low) stock market returns could indicate high (low) returns on assets other than stocks.

Foreign currency seems to be the ideal asset class in order to tackle that question as recent studies highlight a close relation between equity market and exchange rate movements over the past two decades. Hau and Rey $(2004,2006)$ provide evidence for a tight, contemporaneous link between relative stock market returns, i.e. the return on the foreign stock market in excess of the return on the domestic stock market, and U.S. dollar exchange rate changes in a sample of developed economies for the post 1990s period. This finding seems to be driven by the observation that gross cross-border equity holdings as well as capital flows between equity markets have increased strongly since the late 1980s (Lane and Milesi-Ferretti (2001, 2007), Hau and Rey (2004)). In addition, Siourounis (2007) shows that equity flows are more important than bond flows in order to predict U.S. dollar exchange rate changes against other major currencies.

Based on these findings, I take the stance of a U.S. investor and form six portfolios of monthly foreign currency excess returns according to the past short-term performance of the respective foreign stock markets, i.e. momentum in foreign stock market returns. These stock market momentum sorted currency portfolios reveal a clear pattern: Past, relatively low foreign stock market returns are associated with currently low foreign currency excess returns and vice versa for the sample period from November 1983 to May 2009. Momentum in stock market returns can be exploited as signal for risk premia on foreign currencies. This finding holds for different momentum strategies, pertains after taking account of transaction costs and applies to samples of both developed and emerging markets as well as for developed markets only.

Dissecting the portfolio currency excess returns into forward discounts, i.e. the spread between forward and spot exchange rates, and spot exchange rate changes reveals that past, high cumulated foreign stock market returns signal a foreign currency appreciation. But the 
portfolio excess returns appear to be unrelated to forward discounts. This finding is interesting against the backdrop of Lustig and Verdelhan (2007) and Lustig, Roussanov and Verdelhan (2009) who form currency portfolios based on interest rate differentials or forward discounts. High interest rate differentials are associated with high currency excess returns. This observation is driven by the high exposure of high interest rate currencies to systematic risks. It hence provides a risk-based explanation for the empirical failure of the uncovered interest rate parity condition (UIP).

The clear pattern in currency portfolio returns sorted with respect to stock market momentum, however, is unrelated to the respective currencies' forward discounts. Further analysis of these currency portfolios provides three main findings.

First, time series variation in monthly stock market momentum sorted currency portfolio returns and the associated carry trade, going long in past stock market winner and short in stock market loser currencies, are partly explained by the TED spread, the spread between a risk-free T-bill rate and the LIBOR eurodollar deposit rate, a measure of liquidity or crash risk that Brunnermeier, Nagel and Pedersen (2009) find to be important in order to explain typical carry trade returns, i.e. long positions in high forward discount and short positions in low forward discount currencies. This finding is hence not a unique feature of the stock market momentum currency portfolio returns but also pertains to the Lustig et al. (2009) forward discount sorted portfolios. There seems to be common time series variation in currency portfolio returns formed with respect to forward discounts and foreign stock market momentum.

Second, I assess if there is a common source of cross-sectional variation among currency portfolio returns that are sorted according to forward discounts, past currency excess returns (currency momentum) and stock market momentum. This exercise is motivated by recent insights from Lewellen et al. (2009) who question the success of a wide variety of asset pricing models to explain the cross-sectional dispersion in the Fama and French (1993) size and book-to-market sorted stock portfolio returns. Their main argument relates to the fact that the size and book-to-market sorted portfolios exhibit a strong factor structure such that it is relatively easy for a model to claim success on explaining average returns on these portfolios when the respective model's risk factors are only weakly correlated with the factor structure of the test assets. Against this backdrop, the stock market momentum sorted foreign currency portfolios are ideal test assets for the Lustig et al. (2009) two-factor model as they are unrelated to forward discounts. 
Lustig and Verdelhan (2007) show that consumption-based models explain the cross-sectional dispersion in interest rate differential sorted currency portfolio returns while Lustig et al. (2009) propose a two-factor model. This two-factor model prices both forward discount and currency momentum sorted currency portfolio returns because low forward discount or currency momentum portfolio returns load differently on the return difference between high and low forward discount sorted currency portfolios, the "high-minus-low" factor $\left(H M L^{F X}\right)$, than the high forward discount and currency momentum portfolio returns. This finding is driven by the ability of the $H M L^{F X}$ factor to capture the principal component of the currency momentum and forward discount portfolios that rationalizes their cross-sectional return differences jointly. In addition, $H M L^{F X}$ and the underlying currency portfolio returns are closely related to macroeconomic risks (Lustig, Roussanov and Verdelhan (2008), Nitschka (2010)).

The cross-sectional dispersion in the foreign stock market momentum sorted currency portfolio returns under study, however, is neither explained by differences in sensitivities to macroeconomic factors such as consumption growth or changes in industrial production, though the latter variable helps to explain momentum in U.S. stock returns (Liu and Zhang (2008)), nor by their exposures to the $H M L^{F X}$ factor. The stock market momentum currency portfolio returns are also unrelated to the principal component of the Lustig et al. (2009) portfolios that reflects a pure currency momentum factor. The evidence of a "common" risk factor in currency returns is hence limited.

Finally, I exploit the evidence of time series predictability to decompose the Lustig et al. (2009) as well as the stock market momentum based currency portfolio returns into permanent components, i.e. those parts of currency returns that are driven by fundamentals, and transitory components, driven by expected returns, following Froot and Ramadorai (2005) and Hoffmann and MacDonald (2009) to shed more light on the relation between currency returns and systematic risks in the cross-section. This empirical exercise is closely related to Campbell and Mei (1993) who use the Campbell (1991) framework to decompose unexpected stock portfolio returns into their cashflow, discount rate and real interest rate components to assess their contribution to the overall stock portfolio return's sensitivity to systematic risk factors. Froot and Ramadorai (2005) translate the Campbell (1991) framework into the exchange rate context and show that in a panel of 18 countries time series variation in currency excess returns is dominated by expected currency return news (the analogue to stocks' discount rate news) while the effect of news about the so called "intrinsic value", i.e. 
news about fundamentals (the analogue to stocks' cashflow news), is limited in the short-run but important over long time horizons (Hoffmann and Mac Donald (2009)).

At first glance, the distinction between permanent and transitory components does not seem to be important for the currency portfolios formed with respect to forward discounts. The sensitivities of the two currency return components to $H M L^{F X}$ move in lockstep with average returns. High sensitivities are associated with high excess returns. But a simple cross-sectional regression shows that rather differences in the permanent components' exposures to $H M L^{F X}$ than the respective transitory components' sensitivities are priced in average excess returns on forward discount sorted currency portfolios in line with recent findings of Galsband and Nitschka (2010). The fundamentally driven components of stock market momentum sorted currency portfolio returns, however, are unrelated to the $H M L^{F X}$ factor which explains the inability of the Lustig et al. (2009) model to capture the cross-sectional dispersion in stock market momentum sorted currency portfolio returns.

The remainder of this paper is organized as follows. Section two provides details of the data, currency portfolio construction and gives descriptive statistics of the currency portfolios in question. Section three assesses the time series variation in the stock market momentum sorted currency portfolios returns. Section four reports if recently proposed pricing models for currency returns explain their cross-sectional variation. This assessment leads to the decomposition of currency portfolio returns into temporary and permanent components in section five. Finally, section six concludes. The appendix contains robustness checks and additional results.

\section{Currency portfolio formation, data and descriptive statistics}

\subsection{Data sources and definition of currency excess returns}

This paper exploits momentum in stock market returns (Asness et al (1997), Bhojraj and Swaminathan (2006)) in order to form portfolios of monthly foreign currency excess returns from a U.S. investor's perspective. I consider a sample of both developed and emerging markets. The countries' respective sample periods are either restricted by the availability of data on currency or stock market returns. The developed markets under study are: Australia (Jan 1985 - May 2009), Austria (Jan 1997 - Dec 1998), Belgium (Jan 1997 - Dec 1998), Canada (Jan 1985 - May 2009), Denmark (Jan 1985 - May 2009), Euro Area (Jan 1999 - May 2009), Finland (Jan 1997 - Dec 1998), France (Nov 1983 - Dec 1998), Germany (Nov 1983 Dec 1998), Greece (Jan 1997 - Dec 2001), Hong Kong (Nov 1983 - May 2009), Ireland (Jan 
1997 - Dec 1998), Italy (Jan 1997 - Dec 1998), Japan (Nov 1983 - May 2009), Netherlands (Nov 1983 - Dec 1998), New Zealand (Dec 1988 - May 2009), Norway (Jan 1985 - May 2009), Portugal (Jan 1997 - Dec 1998), Singapore (Jan 1985 - May 2009), Spain (Jan 1997 Dec 1998), Sweden (Jan 1985 - May 2009), Switzerland (Nov 1983 - May 2009) and the United Kingdom (Nov 1983 - May 2009). The group of emerging markets considered in this paper consists of: Czech Republic (Jan 1997 - May 2009), Hungary (Nov 1997 - May 2009), India (Nov 1997 - May 2009), Indonesia (Jan 1997 - May 2009), Korea (Mar 2002 - May 2009), Kuwait (Jun 2006 - May 2009), Malaysia (Jan 1997 - May 2009), Mexico (Jan 1997 May 2009), Philippines (Jan 1997 - May 2009), Saudi Arabia (May 2006 - May 2009), South Africa (Dec 1993 - May 2009), Taiwan (Jan 1997 - May 2009) and Thailand (Jan 1997 - May 2009).

Since the uncovered interest rate parity condition (UIP) is typically violated in the data, with the exception of high inflation countries (Hansen and Hodrick (1980), Fama (1984), Bansal and Dahlquist (2000)), currency excess returns are defined as

$$
\phi_{t+1}^{k}=i_{t}^{k}-i_{t}-\Delta s_{t+1}^{k}
$$

where $i_{t}^{k}$ is the country $k$ short-term interest rate, $i_{t}$ its home country, here U.S., counterpart and $\Delta s_{t+1}^{k}$ the change in the log spot exchange rate of country $k$ relative to the home currency. An increase in $s$ corresponds to an appreciation of the home or depreciation of the foreign currency. Following Lustig et al. (2009), I exploit that covered interest rate parity usually holds at daily or lower frequencies (Akram, Rime and Sarno (2008)). Hence, interest rate differentials are approximately equal to forward discounts, $i_{t}^{k}-i_{t} \approx f_{t}^{k}-s_{t}^{k}$ with $f_{t}^{k}$ the $\log$ forward exchange rate, such that the currency excess return can be expressed as difference between the forward discount and changes in the spot rate

$$
\phi_{t+1}^{k}=\left(f_{t}^{k}-s_{t}^{k}\right)-\Delta s_{t+1}^{k}
$$

or equivalently as buying a foreign currency in the forward market and selling it one month later in the spot market, i.e.

$$
\phi_{t+1}^{k}=f_{t}^{k}-s_{t+1}^{k}
$$

This reformulation has two advantages. First, forward contracts are actually traded and second, it allows taking account of bid and ask spreads.

The excess return on a long position in foreign currency obeys

$$
\phi_{t+1}^{k, l}=f_{t}^{k, b}-s_{t+1}^{k, a}
$$

while shorting the foreign currency gives 


$$
\phi_{t+1}^{k, s}=-f_{t}^{k, a}+s_{t+1}^{k, b}
$$

where superscript $b$ and $a$ indicate bid and ask values. The data sources for the spot and foreign exchange rates are Barclays and Reuters from Thompson Datastream. End of month values are constructed from daily rates in U.S. dollars.

\subsection{Currency portfolio formation according to stock market return momentum}

Lustig and Verdelhan (2007) and Lustig et al. (2009) show that portfolios formed with respect to interest rate differentials or forward discounts reveal a stable pattern in currency excess returns. High interest rate currencies promise higher excess returns than low interest rate currencies.

This paper, however, examines currency portfolios sorted by past stock market returns. I exploit that high stock market returns tend to be followed by high stock market returns in the near future. This phenomenon, known as momentum, is not only pervasive at the firm-level (Jegadeesh and Titman (1993), Rouwenhorst (1998)) but also present in country stock market returns (Asness, Liew and Stevens (1997), Bhojraj and Swaminathan (2006)). If we are willing to accept a stock market return as proxy for systematic risk, as usually done in empirical tests of the Sharpe (1964) and Lintner (1965) CAPM, then this latter finding suggests that times of high systematic risks also signal risky times in the short run. Hence, high past stock market returns could indicate high returns on foreign currencies given the tight link between stock market returns and exchange rate changes highlighted by Hau and Rey (2004, 2006).

To gauge the plausibility of this argument, this paper forms currency portfolios according to momentum on foreign stock markets. There are several different momentum strategies. This paper presents the results for a 12-2 momentum strategy as examined by Fama and French (1996). 12-2 momentum means that the currency portfolios end of November 1983 are based on the cumulated foreign stock market returns for the time period from November 1982 to September 1983. I use country stock indexes in U.S. dollars, as I take the stance of a U.S. investor, from MSCIBarra to calculate monthly foreign stock market returns and form six currency portfolios for the sample of both developed and emerging countries. The sample period ranges from November 1983 to May 2009. These portfolios are rebalanced every month. The number of countries included in the sample varies over time between 8 and 33 . Portfolio 1 always contains the currencies from countries with lowest past stock returns ("losers") and portfolio 6 the currencies from countries with highest past foreign stock returns 
("winners"). The portfolio currency excess returns are arithmetic averages of the individual currency excess returns allocated to the portfolios.

Table 1 presents descriptive statistics of these 12-2 stock market momentum sorted currency portfolios. Panel A covers the full sample of developed and emerging markets, panel B provides the same information set for a sample of developed countries only. All of the moments are reported in annualized percentage points. Section A.1 in the appendix provides the corresponding results if I follow the 6-6 stock momentum strategy examined by Jegadeesh and Titman (1993). The findings are very similar to those described in the subsequence.

Irrespective of the particular country sample, low past foreign stock market returns signal a depreciation of the foreign currency vis-à-vis the U.S. dollar and vice versa. The stock market loser portfolio's currencies depreciate by 130 basis points on average. Portfolio 2 currencies depreciate less at a rate of 89 basis points. The other stock market momentum sorted currency portfolios appreciate on average. The highest appreciation rate of 281 basis points pertains to portfolio 5. With the exception of portfolio 6, moving from the stock market loser to winner portfolios reveals monotonically increasing appreciation rates of the currencies in the respective portfolios. This finding is more clear-cut in the sample of developed countries which is in line with Hau and Rey $(2004,2006)$. They argue that the contemporaneous link between exchange rates and relative stock market returns pertains especially among developed countries. But the average spot exchange rate changes of the full country sample reveal this pattern as well. The only exception is the portfolio comprised of currencies from the highest stock market momentum return countries.

In addition, table 1 reflects that sorting on stock market momentum is not a disguised version of currency portfolio formation according to forward discount rates. Average forward discounts and currency excess returns of the portfolios seem to be unrelated. The average forward discount of portfolio 1 in the sample comprising all countries, for example, is at 179 basis points, the respective forward discount for the sixth portfolio stands at 188 basis points. It is difficult to reconcile the respective exchange rate depreciation of 130 basis points for portfolio 1 and the appreciation of 109 basis points for portfolio 6 with the corresponding forward discounts.

Confirming previous findings (Asness et al. (1997)), there is evidence of momentum in stock market returns. Low past, cumulated stock market returns are associated with currently low stock market returns and vice versa. This observation is associated with corresponding average exchange rate changes. Stock market loser currencies depreciate against the U.S. dollar, whereas stock market winner currencies appreciate against the U.S. dollar. 
The pattern in currency excess returns is clearly visible, irrespective if we correct for transaction costs. Past, low stock market returns signal low currency excess returns while high, past stock market returns go hand in hand with high currency excess returns. This finding pertains after taking into account bid/ask spreads. Table 1 reports the excess returns net of bid and ask spreads of a short position in portfolio 1, the stock market losers, and long positions in the other portfolios. The biggest difference in excess returns is between portfolios 5 and 1 in panel A of table 1. Net of transaction costs the stock market loser currency portfolio, portfolio 1 , delivers an excess return of -2.75 percentage points while portfolio 5 offers a 3 percentage point return. This return difference between stock market winner and loser currency portfolios is smaller for the developed countries' sample but qualitatively confirms the observation from the full country sample. This finding is comparable to the excess return spreads between forward discount sorted portfolios reported in Lustig et al. (2009).

To alleviate concerns whether these return differences are significant, I test for the equality of the stock market momentum sorted currency portfolio excess returns. The p-value of an ANOVA F-Test of $E\left(\phi^{i}\right)=\mu$ - with $E$ the expectation operator, $\phi^{i}$ the excess return on currency portfolio $i$ - is 0.27 when confronted with the stock market momentum based currency portfolio returns. Hence, the null that all currency portfolio returns are the same is accepted at 27\% significance level. The same test for the Lustig et al. (2009) forward discount sorted currency portfolios ${ }^{2}$ delivers a $\mathrm{p}$-value of 0.21 . To put these numbers into perspective, the p-value of the ANOVA F-Test for monthly returns on the six Fama and French size and book-to-market sorted stock portfolios ${ }^{3}$ is 0.80 for the same sample period ranging from November 1983 to May 2009.

\section{Time series variation in stock market momentum based currency portfolio returns}

The descriptive statistics provided in table 1 suggest a variety of the typical carry trade of going long in high interest rate and going short in low interest rate currencies. This variety requires to buy currencies of past stock market winner countries and sell past stock market loser countries' currencies.

\footnotetext{
${ }^{2}$ Freely available on http://web.mit.edu/adrienv/www/ or http://hlustig2001.squarespace.com

${ }^{3}$ Freely available on $\mathrm{http}: / /$ mba.tuck.dartmouth.edu/pages/faculty/ken.french/data library.html
} 
Burnside et al. (2008) suggest peso problems, i.e. risk averse investors take into account the small probability of a big event's occurrence, are the driving forces of carry trade returns. Consistent with this argument, Brunnermeier, Nagel and Pedersen (2009) show that typical carry trades expose investors to crash and funding liquidity risks. They find that variables that reflect these risks, such as changes in the VIX, the CBOE option implied volatility index, or the spread between the Eurodollar deposit rate and the T-bill rate (TED), help to explain the time series variation in carry trade returns. High levels of $\Delta V I X$ or the TED spread predict future high carry trade returns. Lustig et al. (2008) show that their forward discount sorted currency portfolio returns are highly predictable by the average forward discount rate over all currency portfolios and that these predicted returns are tightly linked to changes in VIX and variables that mirror macroeconomic risks.

Figure 1 highlights that funding liquidity risks, measured by the TED spread, and the stock market momentum sorted currency portfolios are tightly linked as well. The upper panel depicts the relation between the TED spread and the return difference between the stock market winner and the stock market loser currency portfolio over the full sample period from November 1983 to May 2009. The lower panel zooms on this relation during the recent crisis period, here limited to the period from June 2007 to December 2008. Over time the TED spread and the return spread between the high and low stock market momentum currency portfolios widen in times of crisis. This is particularly true for the recent crisis period.

This observation leaves the impression that measures of funding liquidity risk do not only predict returns on typical carry trades, going long in high forward discount and short in low forward discount currencies, but could also predict the time series variation in the stock market momentum sorted currency portfolios and hence the carry trade variety of shorting stock market momentum loser currencies and taking long positions in stock market winner currencies. In order to gauge the plausibility of this argument, table 2 presents evidence from simple one-month ahead forecast regressions of monthly excess returns on the stock market momentum sorted currency portfolios on predictive variables one month ahead. The one month ahead forecast regression takes the following form

$$
\phi_{t, t+1}^{i}=\mu+\beta^{i} x_{t}+\varepsilon_{t, t+1}^{i}
$$

with $\phi_{t, t+1}^{i}$ the monthly currency excess return on currency portfolio $i$ and $x_{t}$ denotes one of the forecasting variables TED or $\triangle V I X$. The sample period of the forecast exercise with TED ranges from November 1983 to May 2009. Changes in VIX are only available since February 1990. The interest rate data to construct TED are from the Federal Reserve Board of Governor's Table H.15. VIX is from finance.yahoo.com. 
Table 2 presents the estimates of $\beta^{i}$ from regression (6). Panels A and B give the results for monthly stock market momentum sorted currency portfolios returns net of transaction costs predicted by TED and $\triangle V I X$ respectively. Panel $\mathrm{C}$ provides the corresponding forecast regression estimates for bid/ask spread adjusted forward discount sorted currency portfolios when regressed on the TED spread. Panel D gives the results of forecast regressions of returns on the carry trade variety suggested in this paper - going short in the stock market loser currency portfolio and long in the other portfolios - on the TED spread.

$$
\phi_{t, t+1}^{i}-\phi_{t, t+1}^{1}=\mu+\beta^{i} T E D_{t}+\varepsilon_{t, t+1}^{i}
$$

Newey - West (Newey and West (1987)) corrected t-statistics are below the estimates in parenthesis. The asterisk indicates significance at the $95 \%$ confidence level. $R^{2}$ denotes the adjusted $R^{2}$.

Note that the Lustig et al. (2009) forward discount sorted portfolios are publicly available. But to allow a direct comparison with the stock market momentum based currency portfolios, it is necessary to take the differences in countries' sample periods into account. For example, there is currency excess return data for South Africa over the whole sample period from November 1983 to May 2009 but stock market returns for South Africa are only available since December 1992. Similar differences in data availability apply to other countries in my sample. Hence, I reconstruct both forward discount and currency momentum currency portfolios using exactly the countries' sample periods from the stock market momentum currency portfolio formation. The descriptive statistics are presented in section A.2 of the appendix. They confirm the basic message provided by Lustig et al. (2009). Excess returns are monotonically increasing from low to high forward discount as well as currency momentum sorted currency portfolios. The correlation of the reconstructed forward discount sorted currency portfolios with the original ones varies from 0.82 to 0.95 .

The forecast regression estimates presented in table 2 highlight that excess returns on the stock market momentum sorted currency portfolios are predictable. As is evident from panel A of table 2, the TED spread predicts monthly currency returns on the extreme stock market winner and loser currency portfolios. High funding liquidity or crash risk mirrored in a positive TED spread is associated with future high currency returns consistent with Brunnermeier et al. (2009). Note that the negative sign of the first portfolio's regressor estimate is due to the convention that I regard a short position in the stock market loser currency portfolio.

Panel B shows that changes in VIX do not help to explain the time variation in stock market momentum based currency returns. Panel C, however, reveals that the predictive power of the 
TED spread is not a unique feature with respect to the stock market momentum currency portfolios but applies to forward discount sorted currency portfolio returns too. Panel D gives the corresponding results for returns on a short position in the stock market loser and long positions in the other currency portfolios. It is clearly evident that the proxy for funding liquidity risk, the TED spread, predicts these returns successfully one month ahead.

Section A.3 in the appendix reports additional estimates from forecast regressions of stock market momentum currency portfolio returns on the macroeconomic predictive variables advocated by Chen, Roll and Ross (1986) which are the yield spread between a 10-year government bond and the 3-month treasury bill (term spread, TS), the spread between Baa rated long-term corporate bonds and the long-term government bond (default spread, DS) and changes in monthly and annual industrial production (MIP, AIP) respectively. Data on a monthly index of industrial production can be obtained from the Federal Reserve Bank of St Louis. The interest rate data is from the Federal Reserve Board of Governors, Table H15. It turns out that these macroeconomic variables hardly explain the risk premia on stock return momentum sorted currency portfolios. These macroeconomic variables, however, fail to explain the time series variation in the stock market momentum sorted currency portfolio returns.

Taken together the evidence from the forecast regressions suggest that time series variation in the stock market momentum sorted currency portfolio returns is explained by the same underlying risks as time variation in forward discount based currency portfolio returns. There seems to be a common source of time variation in currency returns that is related to crash and funding liquidity risks.

\section{$4 \quad$ Pricing foreign currency returns}

Funding liquidity risks drive time series variation in currency returns. This finding is common for both forward discount and stock market momentum sorted currency portfolio returns. This section assesses if there is not only a common source of time series but also of cross-sectional variation in risk premia on foreign currencies.

Motivated by the evidence provided by Lustig and Verdelhan (2007) that consumption-based models explain average returns on interest rate differential sorted currency portfolios, I first assess if covariation with macroeconomic factors explains cross-sectional dispersion in the stock market momentum sorted currency portfolios. Based on Lustig et al. (2009), who show that two risk factors constructed from forward discount sorted currency portfolio returns 
explain both average forward discount as well as currency momentum portfolio returns, I also try to price the stock market momentum currency portfolios with the Lustig et al. (2009) factors. This exercise is motivated by recent insights from Lewellen et al. (2009) who question the success of a wide variety of asset pricing models to explain the cross-sectional dispersion in the Fama and French (1993) size and book-to-market sorted stock portfolio returns. Their main argument relates to the fact that the size and book-to-market sorted portfolios exhibit a strong factor structure such that it is relatively easy for a model to claim success on explaining average returns on these portfolios when the respective model's risk factors are only weakly correlated with the factor structure of the test assets. Against this backdrop, the stock market momentum sorted foreign currency portfolios are ideal test assets for the Lustig et al. (2009) two-factor model as they are unrelated to forward discounts.

\subsection{Macroeconomic factors and stock market momentum sorted currency portfolios}

Liu and Zhang (2008) show that one of the macroeconomic factors identified by Chen et al. (1986), namely changes in industrial production, is priced in returns on momentum sorted U.S. stock portfolios. Hence, this variable could have the potential to explain the currency portfolio returns that are formed with respect to stock market momentum from the U.S. point of view. As suggested by Chen et al. (1986) I lead changes in monthly industrial production. In addition, I assess if consumption growth could be an explanatory variable as Lustig and Verdelhan (2007) show that differences in the exposure to consumption-related risk factors explains the cross-section of excess returns on interest rate differential sorted currency portfolios. Monthly non-durable and services consumption expenditure as well as the respective CPI and population figures to obtain real, per capita consumption growth are from the Bureau of Economic Analysis.

Table 3 summarizes the results of the cross-sectional pricing exercise. The cross-sectional empirical results conducted in this paper follow from the basic pricing equation

$$
0=E_{t}\left(m_{t+1} \phi_{t+1}^{i}\right)
$$

with $m_{t+1}=\left(1-b f_{t+1}\right)$ where $f_{t+1}$ is the vector of pricing factors, $b$ the vector of corresponding factor loadings and $\phi_{t+1}^{i}$ the excess returns on currency portfolios. I estimate the beta representation of equation (8), i.e. $E_{t}\left(\phi_{t+1}^{i}\right)=\lambda^{\prime} \beta^{i}$, which states that the expected excess return on currency portfolio $i$ equals the factor prices, $\lambda$, times the portfolio specific exposure to the factors, $\beta^{i}$. 
Panel A displays risk price estimates of consumption growth and industrial production growth for the sample comprised of all countries. Panel B presents the corresponding estimates for the developed countries sample. The risk price estimates are obtained from a two-stage FamaMacBeth regression (Fama and MacBeth (1973)).

The first stage is a time series regression of the test asset returns, the returns on currency portfolio $i$, on the risk factors

$$
\phi_{t}^{i}=\mu+\beta^{i} x_{t}+\varepsilon_{t}^{i}
$$

where $x_{t}$ represents either consumption growth , $\Delta c_{t}$, or changes in industrial production, $\Delta \operatorname{mip}_{t}$.

The second stage is a cross-sectional regression of the currency excess returns on the estimated betas at each point in time.

$$
\phi_{t}^{i}=\hat{\beta}^{i} \lambda^{x}+v_{t}^{i}, \forall t
$$

with $\lambda^{x}$ representing the estimated risk price of the factor under consideration. Risk price estimates, mean absolute (mape) as well as mean squared pricing errors (mspe) are reported in percentage points per annum. Shanken (1992) corrected t-statistics appear below the risk price estimates in parenthesis.

The main message of the results presented in table 3 is easily summarized. Neither differences in the exposures to consumption growth nor to changes in industrial production growth explain different average excess returns on the past stock return sorted currency portfolios. Covariation with macroeconomic risk factors does not rationalize the pattern in the currency portfolio returns formed with respect to momentum returns on the respective stock markets. Estimating (10) with time-varying betas, obtained from rolling window regressions, delivers similar results.

\subsection{Common risk factors in currency excess returns?}

Lustig et al. (2009) show that excess returns on currency portfolios formed according to interest rate differentials or forward discounts inherit all the necessary information to explain their cross-sectional differences. The two first principal components suffice to explain over 80 percent of the variation in forward discount sorted currency excess returns. The first principal component is highly correlated with the average returns on the currency portfolios while the second principal component is closely related to the return difference between the high and low forward discount currency portfolios. Differences in the exposure to this "high-minuslow" risk factor, $H M L^{F X}$, explain most of the cross-sectional variation in currency excess 
returns. This finding also pertains to currency momentum sorted portfolios as $H M L^{F X}$ captures that principal component of forward discount and currency momentum sorted portfolios returns that represents long positions both in high forward discount and high currency momentum portfolios and short positions in the respective low forward discount and currency momentum portfolios.

Figure 2 presents the covariance of the reconstructed Lustig et al. (2009) currency portfolio returns with their principal components against their average returns thus basically replicating Figure 3 in Lustig et al. (2009). This graph is organized as follows. The points connected by the straight line represent the covariances of the forward discount (portfolios 1 to 6) and currency momentum (portfolios 7 to 12) sorted currency portfolio returns with one of the 12 principal components. The points around the dashed line are the respective mean currency excess returns. The upper left picture in the first line displays the relation of covariances with the first principal component and average currency returns. The picture to the lower right gives the respective graph for the $12^{\text {th }}$ principal component. Figure 2 highlights that the reconstruction of the forward discount and currency momentum portfolios of Lustig et al. (2009) does not alter any of the conclusions with respect to the relation of currency returns and their principal components. It is evident that the second principal component represents a pure currency momentum factor and the third one the common risk factor in currency returns. Figure 3 provides the corresponding picture of covariances of the stock market momentum currency portfolios with the Lustig et al. (2009) principal components relative to their mean excess returns. There is neither a relation between those currency portfolio returns and the currency momentum factor nor with the common risk factor among forward discount and currency momentum sorted currency portfolios.

Panel A of table 4 presents the corresponding pricing exercise, i.e. the risk price estimates of the two-factor Lustig et al. (2009) model when confronted with the stock market momentum currency portfolios, i.e.

$$
E_{t}\left(\phi_{t}^{i}\right)=\hat{\beta}_{R F X}^{i} \lambda_{R F X}+\hat{\beta}_{H M L F X}^{i} \lambda_{H M F X}
$$

with RFX indicating the average currency portfolio excess return, the dollar factor in the terms of Lustig et al. (2009), and HMLFX indicating $H M L^{F X}$. The risk prices are again obtained from a Fama-MacBeth regression and reported in percentage points per annum. Shanken corrected t-statistics are below the estimates in parenthesis. Panel B of table 4 gives the estimates from the first stage time series regression

$$
\phi_{t}^{i}=\alpha^{i}+\beta_{R F X}^{i} R_{t}^{F X}+\beta_{H M L F X}^{i} H M L_{t}^{F X}+\varepsilon_{t}^{i}
$$

with Newey-West (Newey and West (1987)) corrected t-statistics in parenthesis. 
Contrary to the impression left by figure 3, the cross-sectional results in panel A of table 4 suggest that the Lustig et al. (2009) two-factor model does not perform too badly when confronted with the six currency portfolios based on stock market momentum returns. The estimated risk price of the high-minus-low forward discount factor, $H M L^{F X}$, of 9.26 percentage points p.a. is marginally insignificant but in the range of its sample mean of 8.74 percentage points. About two thirds of the cross-sectional variation is explained by the twofactor model. Figure 4, however, paints a less positive picture. It depicts the average returns predicted by the model on the horizontal axis and the actual currency portfolio excess returns on the vertical axis. The two Lustig et al. (2009) risk factors do a remarkable job in explaining the stock market loser currency portfolio (portfolio 1). However, the excess returns on portfolios 2, 3, 5 and 6 predicted by the model are virtually the same. Taken together the cross-sectional fit of the model is poor relative to its performance for forward discount and currency momentum sorted currency portfolio returns.

Panel B of table 4 presents the first stage time series estimates from the Fama-MacBeth regression. Since the previous section stressed that both forward discount and stock market momentum sorted currency portfolio returns are driven by funding liquidity risks, it is not too surprising that the Lustig et al. (2009) model does well in explaining the stock market momentum based currency returns in the time series. The two factors capture between 63 and 74 percent of the time series variation in the excess returns on currency portfolios sorted according to momentum in foreign stock market returns. Time series pricing errors, alphas, are individually insignificant with the exception of portfolio 2. However, a p-value of 0.0 for the Gibbons, Ross and Shanken (1989) test leaves the impression that we reject the hypothesis of all pricing errors being jointly zero.

Hence, the cross-sectional pricing exercise reflects the impression left by figure 2 . The risk factors that capture the cross-sectional dispersion in forward discount and currency momentum do not explain the cross-sectional dispersion in the stock market momentum based currency portfolios. The appendix provides cross-sectional and time series regression estimates for two pricing factors constructed from the currency momentum portfolios (see section A.4 of the appendix). These results are very similar to the findings presented in this section. In addition, section A.5 in the appendix provides details for an example of a conditional model that features the TED spread as conditioning variable. The cross-sectional performance of this conditional model seems to be a success. Its time series performance, however, is considerably worse than for the Lustig et al. (2009) two factor model reflecting the more general criticism regarding the usefulness of conditional models by Lewellen and 
Nagel (2006). Finally, section A.6 in the appendix assesses if risk factors constructed from the stock market momentum currency portfolios rationalize cross-sectional dispersion in the Lustig et al. (2009) portfolios. The pattern is similar to what is reported above. The factors constructed from stock market momentum currency portfolios capture the time series variation in the Lustig et. al. (2009) returns relatively well but fails to explain their crosssectional dispersion. Evidence for a really "common" risk factor in average currency returns is limited.

\section{$5 \quad$ Permanent and transitory components in currency returns}

The previous sections highlight that time series variation in stock market momentum sorted currency portfolios is rationalized by one of the variables that explains time series variation in forward discount rate sorted currency portfolios. On the other hand, average excess returns on stock market momentum sorted currency portfolios are hard to explain by their covariation with macroeconomically related currency risk factors proposed recently. Froot and Ramadorai (2005) argue that the distinction between permanent and transitory currency return components is important to understand the relation between currencies and fundamentals. ${ }^{4}$ They translate the Campbell (1991) stock return decomposition framework into the exchange rate context to distinguish between currency returns components that are driven by news about expected returns and intrinsic value news ("cashflow news" in the context of common stocks). They use a panel of daily observed 18 currency returns to show that the time series variation in currency returns is dominated by news about expected returns. In this context, Galsband and Nitschka (2010) show that the Lustig et al. (2009) two factor model explains the cross-sectional dispersion in the permanent, i.e. fundamentally driven, parts of forward discount and currency momentum sorted foreign currency portfolio returns. They are following Campbell and Mei (1993) who employ the framework of Campbell (1991) to decompose the sensitivities of stock portfolio returns to risk factors into components that can be attributed to news about the stock portfolios' cashflows, expected returns and real interest rates. The importance of each of the three components as determinants of sensitivities to systematic risk factors differs across different portfolio sorts.

The decomposition into permanent and transitory components relies on the use of a vector autoregression (VAR). The state vector in this VAR consists of the currency return and

\footnotetext{
${ }^{4}$ Hoffmann and MacDonald (2009) provide evidence for a tight link between time variation in real exchange rates and shocks to real interest rates (permanent shocks) over time when measured at long horizons.
} 
predictive variables such that the expected return news component can be directly backed out from the VAR. The permanent component is the residual.

The time series evidence in section 3 shows that both forward discount and stock market momentum sorted currency portfolio returns are predictable by the TED spread. There is hence evidence for a common source of time series variation. This finding suggests that the transitory components of these returns, i.e. the components that are directly estimated in a VAR of currency returns and predictive variables, should be similar in terms of exposures to systematic risk factors. But their permanent components could have very different sensitivities to risk factors. Average excess returns on stock market momentum sorted currency portfolios are hard to explain by risk factors which have proven their explanatory power for forward discount currency portfolio returns. This observation could be the outcome of substantial differences in the importance of transitory and permanent news for the sensitivities to risk factors. Campbell, Polk and Vuolteenaho (2009), for instance, find that the cashflow components of value (high book-to-market value) and growth (low book-to-market value) stock portfolio returns largely drive the sensitivity to innovations in the CAPM market return.

To gauge if a similar argument applies to the currency returns under study, this section first briefly summarizes the basics of the Froot and Ramadorai (2005) and Hoffmann and Mac Donald (2009) decomposition of currency returns into permanent (intrinsic value) and transitory (expected return) components. Then I focus on the relation between the Lustig et al. (2009) $H M L^{F X}$ factor and the different news components of the forward discount and stock market momentum sorted currency portfolio returns. Therefore, I present some details of the VARs that break the currency returns into permanent and transitory components as well as extract innovations in the $H M L^{F X}$ factor. Finally, this paper provides evidence that the betas of the transitory currency return components with respect to the $H M L^{F X}$ factor are closely related to average returns. High betas of the transitory components are associated with high average currency returns and vice versa. This finding holds for both portfolio sorts but does not pertain to the permanent components of the stock market momentum sorted currency portfolio returns.

\subsection{Decomposition of currency returns into permanent and transitory components}

This section briefly describes the approach of Froot and Ramadorai (2005) to decompose currency returns into their permanent and transitory components that is based on the 
corresponding decomposition of stock returns suggested by Campbell (1991). The starting point is the earlier used definition of a currency excess return

$$
\phi_{t+1}^{k}=i_{t}^{k}-i_{t}-\Delta s_{t+1}^{k}
$$

where $i_{t}^{k}$ is the country $k$ short-term interest rate, $i_{t}$ its home country, here U.S., counterpart and $\Delta s_{t+1}^{k}$ the change in the log spot exchange rate of country $k$ relative to the home currency. As covered interest rate parity tends to hold empirically, we can rewrite (13) to

$$
\phi_{t+1}=\left(f_{t}-s_{t}\right)-\Delta s_{t+1}
$$

with $f_{t}$ the forward exchange rate at time $t$ that fixes the exchange rate in period $t+1$, such that

$$
s_{t}=\phi_{t+1}-f d_{t}-\Delta s_{t+1}
$$

with $f d_{t}=f_{t}-s_{t}$, the forward discount. Iterating forward to the infinite horizon finally gives

$$
s_{t}=E_{t}\left(\sum_{i=1}^{\infty} \phi_{t+i}-f d_{t+i-1}\right)
$$

Combining (14) and (16) delivers the analogue of the Froot and Ramadorai (2005) formulation of unexpected movements in the currency return

$$
\phi_{t+1}-E_{t}\left(\phi_{t+1}\right)=\left(E_{t+1}-E_{t}\right) \sum_{i=1}^{\infty} \phi_{t+i}-f d_{t+i-1}
$$

News about fundamentals or in the terms of Froot and Ramadorai (2005) "intrinsic value" are defined as $\eta_{i v, t}=\left(E_{t+1}-E_{t}\right) \sum_{i=1}^{\infty} f d_{t+i-1}$ and accordingly expected return news obey $\eta_{e r, t}=\left(E_{t+1}-E_{t}\right) \sum_{i=1}^{\infty} \phi_{t+i}$

In order to identify permanent and transitory components in currency returns, Froot and Ramadorai (2005) follow Campbell (1991) using a first-order VAR

$$
z_{t+1}=\mu+\Gamma z_{t}+u_{t+1}
$$

where $z_{t+1}$ is a k-by-1 state vector with the currency excess return on portfolio $i, \phi_{t+1}^{i}$, as first element and variables which predict the currency returns, $\mu$ is a k-by- 1 vector of constants and $\Gamma$ a k-by-k matrix of VAR parameters. Shocks are i.i.d. and represented by the k-by-1 vector $u_{t+1}$. The assumption of a first-order VAR is not restrictive because a higher-order VAR can be written in first-order companion form (Campbell and Shiller (1988)). 
Since the state vector, $\boldsymbol{z}_{t+1}$, includes variables that predict currency returns, the transitory, expected return news component is directly estimated in the VAR whereas the intrinsic value, permanent news component is a residual. It is that part of the currency return which is not explained by the state variables.

Under the assumption that the data is generated by (18), forecasts of future returns obey

$$
E_{t} \phi_{t+1+j}=\mathrm{el}^{\prime} \Gamma^{j+1} z_{t}
$$

with $e 1$ a k-by-1 vector whose first element is one and all other elements zero. The discounted sum of changes in the expectation of future returns, i.e. the expected return news component of the currency return, can thus be written as

$$
\begin{aligned}
& \eta_{e r, t+1} \equiv\left(E_{t+1}-E_{t}\right) \sum_{j=1}^{\infty} \rho^{j} \Delta \phi_{t++j} \\
& \eta_{e r, t+1}=e 1^{\prime} \sum_{j=1}^{\infty} \rho^{j} \Gamma^{j} u_{t+1} \\
& \eta_{e r, t+1}=e 1^{\prime} \rho \Gamma(I-\rho \Gamma)^{-1} u_{t+1}=\lambda^{\prime} u_{t+1}
\end{aligned}
$$

with $\lambda^{\prime}=e 1^{\prime} \rho \Gamma(I-\rho)^{-1}$. The intrinsic value news component is then given by

$$
\eta_{i v, t+1}=\left(e 1^{\prime}+\lambda^{\prime}\right) u_{t+1}
$$

implied by equations (17) and (20) because innovations to the currency return, $\eta_{\phi, t+1}$ can be picked out with $e 1^{\prime} u_{\mathrm{t}+1}$ such that

$$
\eta_{\phi, t+1}=\eta_{i v, t+1}-\eta_{e r, t+1}
$$

In the subsequence, I follow Campbell and Mei (1993) and use unconditional variances and covariances of innovations in the currency returns as well as the $H M L^{F X}$ factor to examine what components of the currency returns determine the sensitivity to the $H M L^{F X}$ factor. The sensitivities are hence defined as

$$
\beta_{H M L F X}^{i} \equiv \frac{\operatorname{cov}\left(\eta_{\phi}^{i}, \eta_{\text {HMLFX }}\right)}{\operatorname{var}\left(\eta_{\text {HMLFX }}\right)}
$$


with $\eta_{H M L F X}$ the innovation in the $H M L^{F X}$ factor and $\eta_{\phi}^{i}$ the unexpected currency return. Given (22) from above, these betas can be decomposed into

$$
\beta_{H M L F X}^{i}=\frac{\operatorname{cov}\left(\eta_{i v}^{i}, \eta_{H M L F X}\right)}{\operatorname{var}\left(\eta_{H M L F X}\right)}-\frac{\operatorname{cov}\left(\eta_{e r}^{i}, \eta_{H M L F X}\right)}{\operatorname{var}\left(\eta_{H M L F X}\right)}=\beta_{i v}^{i}-\beta_{e r}^{i}
$$

which allows to quantify the contribution of the two news components to the sensitivity to $H M L^{F X}$.

\subsection{VAR estimates}

In order to compare differences in the sensitivities of permanent and transitory components to systematic sources of risk, I use the same set of state variables for all of the different currency portfolio sorts. The previously presented time series evidence has shown that the TED spread predicts stock market momentum as well as forward discount sorted currency portfolio returns. In addition to this variable, I consider the respective portfolios' forward discounts as predictive variables. Innovations of the $H M L^{F X}$ factor are obtained from a VAR that consists of the return on the factor, i.e. the return difference between the highest and lowest forward discount sorted currency portfolio, the TED spread and the differences in the respective two portfolios' forward discounts following the predictability assessment of carry trade returns in Lustig et al. (2008). All of the results reported in the subsequence do not rely on this particular combination of state variables in the VAR. Decompositions using only forward discounts or the TED spread as predictive variable yield very similar results.

Table 7 reports the return forecasting equations from the VARs of the $H M L^{F X}$ factor (Panel A), forward discount (panel B) and the stock market momentum sorted currency portfolio returns (panel C). I consider a lag length of one month as suggested by standard information criteria. The table gives the estimates from regressions of the currency portfolio returns on the lagged currency portfolio return, the lagged TED spread and forward discounts. T-statistics in parenthesis are Newey and West (1987) corrected. The $R^{2}$ is adjusted for the number of regressors. Portfolio 1 always includes the low forward discount and stock market momentum currencies. Increasing portfolio numbers indicate increasing levels of the respective portfolio characteristic.

The return on the $H M L^{F X}$ factor is slightly predictable by the forward discounts in line with Lustig et al. (2008). Independent of the characteristic that underlies the currency portfolio formation, we observe predictability of the currency returns by both TED spread and the portfolios' forward discounts. The degree of predictability is very similar across the different portfolio sorts. On average the correlation between expected return and intrinsic value news is 
about -0.70 across all of the currency portfolios, i.e. the portfolios' two different news components are almost orthogonal to each other.

\subsection{Permanent and transitory components of currency portfolio returns: exposures to systematic risks and cross-sectional differences in currency portfolio returns}

This section assesses the relation of permanent, i.e. fundamentally driven, and transitory, driven by the expectation of future returns, components of currency returns with systematic sources of risk. The baseline model is the Lustig et al. (2009) two-factor model. The Lustig et al. (2009) model works well when confronted with forward discount and currency momentum sorted currency portfolio returns but basically fails to explain the cross-sectional differences in stock market momentum sorted currency portfolios.

Figures 5 and 6 visualize the relation between average currency portfolio returns and the betas of the respective intrinsic value and expected return news components' sensitivity to innovations of the $H M L^{F X}$ factor. The innovations of the $H M L^{F X}$ factor, intrinsic value and expected returns news components of the forward discount rate components are obtained from VARs described earlier. The figures present the average returns in percentage points p.a. on the vertical axis and the respective permanent components' betas with respect to the $H M L^{F X}$ factor (upper panel) as well as the transitory components' betas (lower panel).

Figure 5 shows that high $H M L^{F X}$ betas go hand in hand with high average returns irrespective if we regard permanent or transitory components of the forward discount sorted currency portfolios. Figure 6 visualizes the corresponding exercise for the stock market momentum sorted currency portfolios. As conjectured, there is a positive relation between the transitory components and average returns. High average excess returns are associated with high $H M L^{F X}$ betas. This finding reflects the fact that expected returns news are those components of the currency returns that are explained by the predictive variables used in the VAR. As the time series evidence presented in this paper suggests, there seems to be a common source of time variation in forward discount and stock market momentum sorted currency portfolio returns. Hence the transitory components are very similar with respect to their sensitivities to the $H M L^{F X}$ factor. This observation, however, does not pertain to the permanent components of the stock market momentum sorted currency portfolios as the lower panel of figure 6 displays.

The Lustig et al. (2009) model captures the cross-sectional variation of forward discount sorted currency portfolios but fails to explain average stock market momentum sorted currency returns. This paper has shown that in the time series both currency return sorts are 
explained by the same variables which leads to the observation that betas with $H M L^{F X}$ of both portfolio sorts' transitory components move in lockstep with average currency returns. But this is not true for permanent components of the stock momentum currency returns.

A simple cross-sectional regression of the forward discount sorted currency returns under study on the $H M L^{F X}$ betas of their permanent and transitory components delivers a risk price of the transitory components $H M L^{F X}$ sensitivity of 2.40 percentage points with a t-stat of 0.06 while differences in the permanent components' exposure to $H M L^{F X}$ give a risk price of 6.51 with a t-stat of 1.48. This finding suggests that indeed differences in the exposure of the permanent components to innovations of $H M L^{F X}$ seem to be responsible for the crosssectional explanation by the Lustig et al. model rather than differences in the transitory components' sensitivities to $H M L^{F X}$. This conclusion is in line with recent evidence by Galsband and Nitschka (2010) who show that the sensitivity of forward discount portfolios' permanent currency return components to the stock market's cashflow and discount rate news explain their overall market betas. The Lustig et al. (2009) model, however, does not capture the fundamentals driving the stock market momentum sorted currency portfolio returns.

\section{Conclusions}

This paper exploits momentum in stock market returns to form portfolios of foreign currencies. Past, high cumulated foreign stock market returns do not only signal high stock market returns in the near future but also high excess returns on the respective currencies. This paper shows that models that proved their explanatory power for cross-sectional differences in forward discount and currency momentum sorted foreign currency portfolios are not successful when confronted with the stock market momentum based currency portfolio returns. The distinction between permanent and transitory components in currency returns sheds some light on the reasons why these models do not help to rationalize the crosssectional dispersion in currency portfolios allocated according to foreign stock market momentum. However, the TED spread, a measure of funding liquidity risk, explains the time series variation of these portfolio returns just as for forward discount sorted currency portfolios thus highlighting that there is a common source of time series variation in currency returns related to crash or funding liquidity risk. 


\section{References}

Akram, F, Rime D. and L. Sarno (2008), “Arbitrage in the Foreign Exchange Market: Turning on the Microscope", Journal of International Economics 76, 237-253.

Asness, C.S., Liew, J.M. and R. L. Stevens (1997), "Parallels Between the Cross-Sectional Predictability of Stock and Country Returns", Journal of Portfolio Management 23, 79-87.

Bansal, R. and Dahlquist, M. (2000), "The Forward Premium Puzzle: Different Tales from Developed and Emerging Markets", Journal of International Economics 51, 115-144.

Brunnermeier, M., Nagel S. and L.H. Pedersen (2009), "Carry Trades and Currency Crashes", NBER Macroeconomics Annual 2008, 313-347.

Burnside, C., Kleshcheski, I., Eichenbaum, M. and S. Rebelo (2008), "Can Peso Problems Explain the Returns to the Carry Trade?", NBER working paper 14054.

Bhojraj, S. and B. Swaminathan (2006), "Macromomentum: Returns Predictability in International Equity Indices", Journal of Business 79, 429-451.

Campbell, J.Y. (1991), “A variance decomposition for stock returns”, Economic Journal 101, 157-179.

Campbell, J.Y. and J. Mei (1993), "Where do Betas Come From? Asset Price Dynamics and the Sources of Systematic Risk", Review of Financial Studies 6, 567-592.

Campbell, J.Y., Polk, C. and T. Vuolteenaho (2009), "Growth or Glamour? Fundamentals and Systematic Risk in Stock Returns”, Review of Financial Studies forthcoming

Campbell, J.Y. and R.J. Shiller (1988), "The dividend-price ratio and expectations of future dividends and discount factors", Review of Financial Studies 1, 195-228.

Chen, N., Roll, R. and S.A. Ross (1986), "Economic Forces and the Stock Market", Journal of Business 59, 383-483.

Fama, E.F. (1984), "Forward and Spot Exchange Rates", Journal of Monetary Economics 14, 319-338.

Fama, E.F. and K.R. French (1996), "Multifactor Explanations of Asset Pricing Anomalies", Journal of Finance 51, 55-84.

Fama, E. F. and J.D. MacBeth (1973), "Risk, Return and Equilibrium: Empirical Tests", Journal of Political Economy, 81, 607-631.

Froot, K. A. and T. Ramadorai (2005), "Currency Returns, Intrinsic Value, and InstitutionalInvestor Flows”, Journal of Finance 60, 1535-1566.

Galsband, V. and T. Nitschka (2010), "Foreign currency returns and systematic risks", mimeo, January 2010.

Gibbons, M.R., Ross, S.A. and J. Shanken (1989), "A Test of the Efficiency of a Given Portfolio", Econometrica 57, 1121-1152. 
Hansen, L.P. and R.J. Hodrick (1980), "Forward Exchange Rates as Optimal Predictors of Future Spot Rates: An Econometric Analysis", Journal of Political Economy 88, 829-853.

Hau, H. and H. Rey (2004), "Can Portfolio Rebalancing Explain The Dynamics Of Equity Returns And Exchange Rates?", American Economic Review P\&P 94, 126-133.

Hau, H. and H. Rey (2006), "Exchange Rates, Equity Prices and Capital Flows", Review of Financial Studies 19, 273-317.

Hoffmann, M. and R. MacDonald (2009), "Real Exchange Rates and Real Interest Rate Differentials: a Present Value Interpretation”, European Economic Review forthcoming

Jegadeesh, N. and S. Titman (1993), "Returns to buying winners and selling losers: Implications for stock market efficiency", Journal of Finance 48, 65-91.

Lane, P. and G.M. Milesi-Ferretti (2001), "The External Wealth of Nations: Measures of Foreign Assets and Liabilities for Industrial and Developing Nations", Journal of International Economics 55, 263-294.

Lane, P. and G.M. Milesi-Ferretti (2007), "The external wealth of nations mark II: Revised and extend estimates of foreign assets and liabilities, 1970-2004", Journal of International Economics 73, 223-250.

Lewellen, J. and S. Nagel (2006), "The conditonal CAPM does not explain asset pricing anomalies", Journal of Financial Economics 82, 289-314.

Lewellen, J., Nagel, S. and J. Shanken (2009), "A sceptical appraisal of asset pricing tests", forthcoming Journal of Financial Economics, DOI: 10.1016/j.jfineco.2009.09.001

Lintner, J. (1965) The valuation of risk assets and the selection of risky investments in stock portfolios and capital budgets. Review of Economics and Statistics , 47, 13-37.

Liu, L.X. and L. Zhang (2008), "Momentum Profits, Factor Pricing, and Macroeconomic Risk", Review of Financial Studies 21, 2417-2448.

Lustig, H., Roussanov, N. and A. Verdelhan (2008), "Common Risk Factors in Currency Markets", NBER working paper 14082.

Lustig, H., Roussanov, N. and A. Verdelhan (2009), "Common Risk Factors in Currency Markets", mimeo, April 2009

Lustig, H. and A. Verdelhan (2007), "The Cross-section of Foreign Currency Risk Premia and U.S. Consumption Growth Risk", American Economic Review 97, 89-117.

Newey W.K. and K.D. West (1987), "A simple, positive semidefinite, heteroskedasticity and autocorrelation consistent covariance matrix", Econometrica 55, 703-708.

Nitschka, T. (2010), "Idiosyncratic Consumption Risk and Predictability of the Carry Trade Premium: Euro Area Evidence" Financial Markets and Portfolio Management 24, 49-65. 
Rouwenhorst, G.K. (1998), "International momentum strategies", Journal of Finance 53, 267283.

Siourounis, G. (2007), "Capital Flows and Exchange Rates: An Empirical Analysis", mimeo, University of Peloponnese.

Shanken, J. (1992), "On the Estimation of Beta-Pricing Models", Review of Financial Studies, $5,1-33$.

Sharpe, W. F. (1964) Capital asset prices: A theory of market equilibrium under conditions of risk. Journal of Finance 19, 425-442. 


\section{Tables}

Table 1: Descriptive statistics of stock market momentum sorted currency portfolios

\begin{tabular}{|c|c|c|c|c|c|c|c|c|c|c|c|}
\hline \multirow[t]{3}{*}{ Portfolios } & $\bar{~} 1$ & 2 & 3 & 4 & 5 & 6 & 1 & 2 & 3 & 4 & 5 \\
\hline & \multicolumn{6}{|c|}{ Panel A: All countries } & \multicolumn{5}{|c|}{ Panel B: Developed countries } \\
\hline & \multicolumn{6}{|c|}{ Spot exchange rate changes } & \multicolumn{5}{|c|}{ Spot exchange rate changes } \\
\hline Mean & 1.30 & 0.89 & -0.17 & -1.04 & -2.81 & -1.09 & 1.04 & -0.60 & -1.79 & -2.70 & -3.19 \\
\hline STD & 9.79 & 9.12 & 8.77 & 8.59 & 8.27 & 7.99 & 9.82 & 10.52 & 9.30 & 9.61 & 9.76 \\
\hline
\end{tabular}

\begin{tabular}{cccccccccccc}
\hline & \multicolumn{4}{c}{ Forward discounts } & \multicolumn{4}{c}{ Forward discounts } \\
Mean & 1.79 & 1.63 & 1.31 & 1.49 & 1.48 & 1.88 & 0.58 & 0.88 & 0.74 & 0.80 & 0.26 \\
STD & 1.59 & 1.37 & 1.09 & 1.23 & 1.50 & 1.74 & 0.94 & 0.87 & 0.85 & 0.74 & 0.80
\end{tabular}

\begin{tabular}{cccccccccccc}
\hline & \multicolumn{4}{c}{ Stock returns } & \multicolumn{4}{c}{ Stock returns } \\
Mean & 6.76 & 10.18 & 10.64 & 11.64 & 15.68 & 15.11 & 7.00 & 11.16 & 10.64 & 11.70 & 15.75 \\
STD & 23.99 & 20.11 & 19.98 & 22.28 & 20.15 & 23.10 & 20.44 & 18.67 & 18.11 & 19.55 & 21.46
\end{tabular}

Excess returns

without bid/ask spreads

$\begin{array}{cccccccc}\text { Mean } & 0.49 & 0.74 & 1.48 & 2.53 & 4.29 & 2.96 & -0.46 \\ \text { STD } & 9.82 & 9.24 & 8.80 & 8.68 & 8.64 & 8.12 & 9.88 \\ \text { SR } & 0.05 & 0.08 & 0.17 & 0.29 & 0.50 & 0.37 & -0.05\end{array}$

\section{Excess returns}

without bid/ask spreads

$\begin{array}{llll}1.48 & 2.54 & 3.50 & 3.45\end{array}$

$\begin{array}{lll}10.58 & 9.41 & 9.69\end{array}$

9.89

$\begin{array}{lll}0.14 & 0.27 & 0.36\end{array}$

0.35

Excess returns with bid/ask spreads

Excess returns with bid/ask spreads

$\begin{array}{cccccccccccc}\text { Mean } & -2.75 & -0.49 & 0.30 & 1.24 & 3.00 & 1.59 & -1.00 & 0.69 & 1.82 & 2.61 & 2.43 \\ \text { STD } & 9.82 & 9.26 & 8.80 & 8.68 & 8.62 & 8.15 & 9.87 & 10.59 & 9.42 & 9.71 & 9.92 \\ \text { SR } & -0.28 & -0.05 & 0.03 & 0.14 & 0.35 & 0.19 & -0.10 & 0.07 & 0.19 & 0.27 & 0.25\end{array}$

Notes: This table provides annualised, percentage point values of average spot exchange rate changes, forward discounts, stock returns, currency excess returns without taking account of transaction costs as well as currency returns computed with bid/ask spreads of 12-2 stock market momentum sorted currency portfolios. Panel A reports the characteristics of these portfolios for the sample of both developed and emerging markets. Panel B displays the corresponding values for a sample of developed countries only. These portfolios are rebalanced every month. "Mean" indicates the arithmetic average of the respective currency portfolio returns, "SD" the corresponding standard deviation and in the case of excess returns "SR" gives the Sharpe ratio, i.e. the ratio of mean returns and standard deviation. The sample period ranges from November 1983 to May 2009. 12-2 momentum means that e.g. foreign currency returns in November 1983 are allocated to portfolios according to the cumulated monthly stock market returns of a particular country in the period from November 1982 to 
September 1983. Portfolio 1 always contains the currencies from countries with lowest, portfolio 6 the currencies from countries with highest stock market momentum returns. 
Table 2: Predictability of stock market momentum

currency portfolio returns

\begin{tabular}{|c|c|c|c|c|c|c|}
\hline Portfolios & 1 & 2 & 3 & 4 & 5 & 6 \\
\hline \multicolumn{7}{|c|}{ Panel A: Stock market momentum } \\
\hline TED & $-\underset{(-1.66)}{2.35}$ & $3.66 *$ & $\underset{(0.71)}{0.95}$ & $\begin{array}{l}1.93 \\
(1.44)\end{array}$ & $3_{(2.62)} .77 *$ & $\underset{(2.29)}{2.56}$ * \\
\hline$R^{2}$ & 0.01 & 0.03 & 0.00 & 0.01 & 0.03 & 0.02 \\
\hline \multicolumn{7}{|c|}{ Panel B: Stock market momentum } \\
\hline$\Delta V I X$ & $-\underset{(-0.13)}{0.00}$ & -0.02 & $-\underset{(-1.21)}{0.01}$ & $\begin{array}{c}-0.01 \\
(-0.61)\end{array}$ & $\underset{(-1.48)}{-0.02}$ & $\begin{array}{c}-0.01 \\
(-1.04)\end{array}$ \\
\hline$R^{2}$ & 0.00 & 0.01 & 0.00 & 0.00 & 0.01 & 0.00 \\
\hline \multicolumn{7}{|c|}{ Panel C: Forward discount } \\
\hline TED & $-{ }_{(-0.88)}^{1.11}$ & $\begin{array}{l}1.92 \\
(1.47)\end{array}$ & ${ }_{(2.54)}^{2.63} *$ & $\underset{(2.00)}{2.72 *}$ & $\underset{(2.05)}{2.95 *}$ & $\underset{(1.98)}{3.82} *$ \\
\hline$R^{2}$ & 0.00 & 0.01 & 0.02 & 0.02 & 0.02 & 0.02 \\
\hline \multicolumn{7}{|c|}{ Panel D: Stock market momentum based carry trade returns } \\
\hline & P6-P1 & P5-P1 & P4-P1 & P3-P1 & P2-P1 & \\
\hline TED & $\underset{(2.05)}{4.91} *$ & $\underset{(2.28)}{6.12} *$ & $\begin{array}{l}4.28 \\
(1.61)\end{array}$ & $\begin{array}{l}3.30 \\
(1.28)\end{array}$ & $\underset{(2.13)}{6.00} *$ & \\
\hline$R^{2}$ & 0.02 & 0.02 & 0.01 & 0.00 & 0.02 & \\
\hline
\end{tabular}

Notes: This table presents estimates of $\beta^{i}$ from the regression $\phi_{t, t+1}^{i}=\mu+\beta^{i} x_{t}+\varepsilon_{t, t+1}^{i}$ with $\phi_{t, t+1}^{i}$ the monthly currency excess return on currency portfolio $i$ and $x_{t}$ denotes one of the forecasting variables TED or $\triangle V I X$. Panel $\mathrm{D}$ gives the results of a forecast regression of carry trade returns based on the stock market momentum sorted currency portfolio returns, i.e. $\phi_{t, t+1}^{i}-\phi_{t, t+1}^{1}=\mu+\beta^{i} x_{t}+\varepsilon_{t, t+1}^{i}$. TED is the spread between the 3-month Treasury bill rate and the 3-month eurodollar deposit rate. $\triangle V I X$ denotes changes in the CBOE option implied volatility index. The sample period of the forecast exercise with TED ranges from November 1983 to May 2009. Changes in VIX are only available since February 1990. Newey - West (Newey and West (1987)) corrected t-statistics are below the estimates in parenthesis. The asterisk indicates significance at the $95 \%$ confidence level. $R^{2}$ denotes the adjusted $R^{2}$. 
Table 3: Risk prices of macroeconomic factors

\begin{tabular}{|c|c|c|c|c|}
\hline \multicolumn{5}{|c|}{ Panel A: full sample } \\
\hline & $\lambda^{x}$ & $R^{2}$ & mape & mspe \\
\hline$\Delta c_{t}$ & $-{ }_{(-0.83)}^{0.10}$ & 0.30 & 1.33 & 2.33 \\
\hline$\Delta \operatorname{mip}_{t}$ & $\begin{array}{l}1.67 \\
(0.53)\end{array}$ & 0.01 & 1.64 & 3.45 \\
\hline \multicolumn{5}{|c|}{ Panel B: developed countries } \\
\hline$\Delta c_{t}$ & $-\underset{(-0.98)}{0.18}$ & 0.48 & 0.78 & 0.92 \\
\hline$\Delta m i p_{t}$ & $\begin{array}{l}2.45 \\
(0.40)\end{array}$ & -0.03 & 1.75 & 3.46 \\
\hline
\end{tabular}

Notes: This table presents risk price estimates from Fama-MacBeth regressions of excess returns on stock market momentum sorted currency portfolios on consumption or monthly industrial production growth respectively. Shanken (1992) corrected t-statistics appear below the estimates in parenthesis. Risk price estimates, mean absolute (mape) as well as mean squared pricing errors (mspe) are reported in percentage points per annum. Panel A gives the results for the sample comprising all countries; panel B displays the corresponding estimates for the sample of developed countries. The sample period ranges from November 1983 to May 2009. 
Table 4: Cross-sectional and time series performance of Lustig et al. (2009) model

Test assets: stock market momentum currency portfolio returns

\begin{tabular}{|c|c|c|c|c|}
\hline \multicolumn{5}{|c|}{ Panel A: Risk price estimates } \\
\hline$\lambda_{R F X}$ & $\lambda_{\text {HMLFX }}$ & $R^{2}$ & mape & mspe \\
\hline$--_{(-0.41)}^{0.73}$ & $\underset{(1.55)}{9.26}$ & 0.65 & 0.87 & 1.21 \\
\hline \multicolumn{5}{|c|}{ Panel B: Time series estimates } \\
\hline & $\alpha^{i}$ & $\beta_{R F X}^{i}$ & $\beta_{H M L F X}^{i}$ & $R^{2}$ \\
\hline $\mathrm{P} 1$ & $\begin{array}{c}-0.47 \\
(-0.39)\end{array}$ & $\underset{(-3.42)}{-0.49}$ & $-{ }_{(-6.19)}^{0.33}$ & 0.66 \\
\hline $\mathrm{P} 2$ & $-\underset{(-2.92)}{2.83}$ & ${ }_{(9.31)}^{1.00}$ & $\begin{array}{l}0.18 \\
(3.19)\end{array}$ & 0.74 \\
\hline P3 & $-\underbrace{1.75}_{(-1.72)}$ & $\begin{array}{l}0.84 \\
(5.78)\end{array}$ & $\begin{array}{l}0.17 \\
(3.62)\end{array}$ & 0.63 \\
\hline P4 & $-\underset{(-0.87)}{0.86}$ & $\begin{array}{l}0.67 \\
(5.57)\end{array}$ & $\begin{array}{l}0.23 \\
(5.48)\end{array}$ & 0.69 \\
\hline P5 & $\begin{array}{l}0.96 \\
(0.94)\end{array}$ & $\underset{(5.23)}{0.84}$ & $\begin{array}{l}0.17 \\
(3.49)\end{array}$ & 0.65 \\
\hline P6 & $-\underset{(-0.31)}{0.31}$ & $\underset{(6.65)}{0.76}$ & $\underset{(4.14)}{0.16}$ & 0.63 \\
\hline
\end{tabular}

Notes: Panel A of this table presents risk price estimates from a two stage Fama-MacBeth regression of excess returns on stock market momentum sorted currency portfolios on the two risk factors proposed by Lustig et al. (2009), i.e. the average return across six forward discount sorted currency portofolio, $R^{F X}$, and the return difference between the high and low forward discount sorted currency portfolios, $H M L^{F X}$. Shanken (1992) corrected t-statistics appear below the estimates in parenthesis. Risk price estimates, mean absolute (mape) as well as mean squared pricing errors (mspe) are reported in percentage points per annum.

Panel B gives the estimates from the first stage of the Fama-MacBeth regression, i.e. the time series regressions of currency portfolio returns on the factors. Newey and West (1987) corrected t-statistics appear below the estimates in parenthesis. $R^{2}$ denotes the adjusted $R^{2}$.

The sample period ranges from November 1983 to May 2009. 
Table 5: Return equations from VARs of currency return decomposition into permanent and transitory components

\begin{tabular}{|c|c|c|c|c|}
\hline \multicolumn{5}{|c|}{ Panel A: $H M L^{F X}$ factor } \\
\hline & $\phi_{t-1}^{i}$ & $T E D_{t-1}^{i}$ & $f d_{t-1}^{\text {high }}-f d_{t-1}^{\text {low }}$ & $R^{2}$ \\
\hline$H M L^{F X}$ & $\underset{(2.79)}{0.16}$ & $\underset{(0.75)}{0.98}$ & $\begin{array}{l}0.59 \\
(3.00)\end{array}$ & 0.06 \\
\hline \multicolumn{5}{|c|}{ Panel B: Forward discount sorted portfolio returns } \\
\hline & $\phi_{t-1}^{i}$ & $T E D_{t-1}^{i}$ & $f d_{t-1}^{i}$ & $R^{2}$ \\
\hline $\mathrm{P} 1$ & $\underset{(0.29)}{0.02}$ & $\underset{(1.13)}{1.24}$ & 1.10 & 0.04 \\
\hline $\mathrm{P} 2$ & $\begin{array}{l}0.09 \\
(1.57)\end{array}$ & $\underbrace{1.41}_{(1.31)}$ & $\underset{(1.00)}{0.97}$ & 0.02 \\
\hline P3 & $\underset{(0.54)}{0.03}$ & $\underset{(2.13)}{2.30}$ & ${ }_{(1.00)}^{1.07}$ & 0.02 \\
\hline $\mathrm{P} 4$ & $\underset{(2.62)}{0.15}$ & $\underset{(1.74)}{1.94}$ & $\underset{(2.03)}{2.03}$ & 0.05 \\
\hline P5 & $\underset{(1.35)}{0.08}$ & $\underset{(2.41)}{2.72}$ & $\underset{(0.59)}{0.51}$ & 0.02 \\
\hline P6 & $\underset{(2.37)}{0.14}$ & $\underset{(1.42)}{2.09}$ & $\underset{(2.86)}{0.71}$ & 0.07 \\
\hline
\end{tabular}

Panel C: Stock market momentum sorted portfolio returns

\begin{tabular}{|c|c|c|c|c|}
\hline & $\phi_{t-1}^{i}$ & $T E D_{t-1}^{i}$ & $f d_{t-1}^{i}$ & $R^{2}$ \\
\hline $\mathrm{P} 1$ & $\begin{array}{l}0.17 \\
(3.00)\end{array}$ & $\frac{-2.01}{(-1.58)}$ & $\underset{(-1.79)}{-0.62}$ & 0.05 \\
\hline $\mathrm{P} 2$ & $\begin{array}{l}0.07 \\
(1.17)\end{array}$ & $\begin{array}{l}3.14 \\
(2.60)\end{array}$ & $\begin{array}{l}0.89 \\
(2.34)\end{array}$ & 0.04 \\
\hline P3 & $\underset{(0.42)}{0.02}$ & $\underset{(0.69)}{0.81}$ & $\begin{array}{l}0.53 \\
(1.12)\end{array}$ & 0.00 \\
\hline P4 & $\frac{-0.00}{(-0.08)}$ & $1_{(1.42)}$ & $\begin{array}{l}0.77 \\
(1.87)\end{array}$ & 0.01 \\
\hline P5 & $\begin{array}{l}0.04 \\
(0.67)\end{array}$ & ${ }_{(2.42)}^{2.76}$ & 1.67 & 0.10 \\
\hline P6 & $\begin{array}{l}0.01 \\
(0.25)\end{array}$ & $\underbrace{1.96}_{(1.79)}$ & $\underset{(2.05)}{0.56}$ & 0.02 \\
\hline
\end{tabular}

Notes: This section presents estimates for the currency return forecasting equation from vector autoregressions (VAR) to decompose the currency portfolio returns into their intrinsic value (permanent) and expected return (transitory) news. The variables considered in the VARs are the respective currency portfolio's excess return, the TED spread, i.e. the spread between the 3-month T-bill and the 3-month Eurodollar deposit rate, as well as the corresponding forward discount for each of the portfolios. For each of the portfolios a separate VAR is run.

Such a VAR is also used to obtain innovations in the Lustig et al. (2009) $H M L^{F X}$ factor.

Panel A gives the corresponding return forecasting equation for the VAR to extract innovation in $H M L^{F X}$, panel B for the decomposition of forward discount sorted and panel $\mathrm{C}$ for the stock market momentum sorted currency portfolio returns. 


\section{Figures}
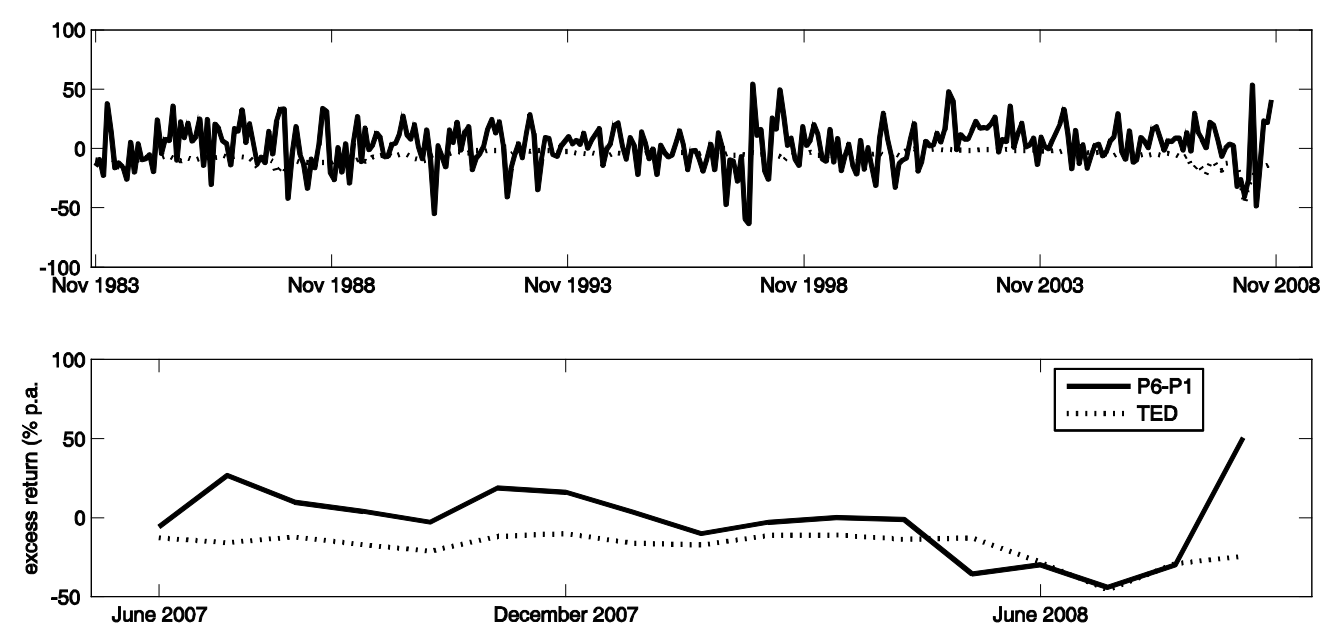

Figure 1: Plot of the TED spread against the returns difference between high and low stock market momentum sorted foreign currency portfolios. The upper panel presents this relationship for the full sample period from November 1983 to May 2009. The lower panel depicts this relationship for the time period from June 2007 to December 2008. 

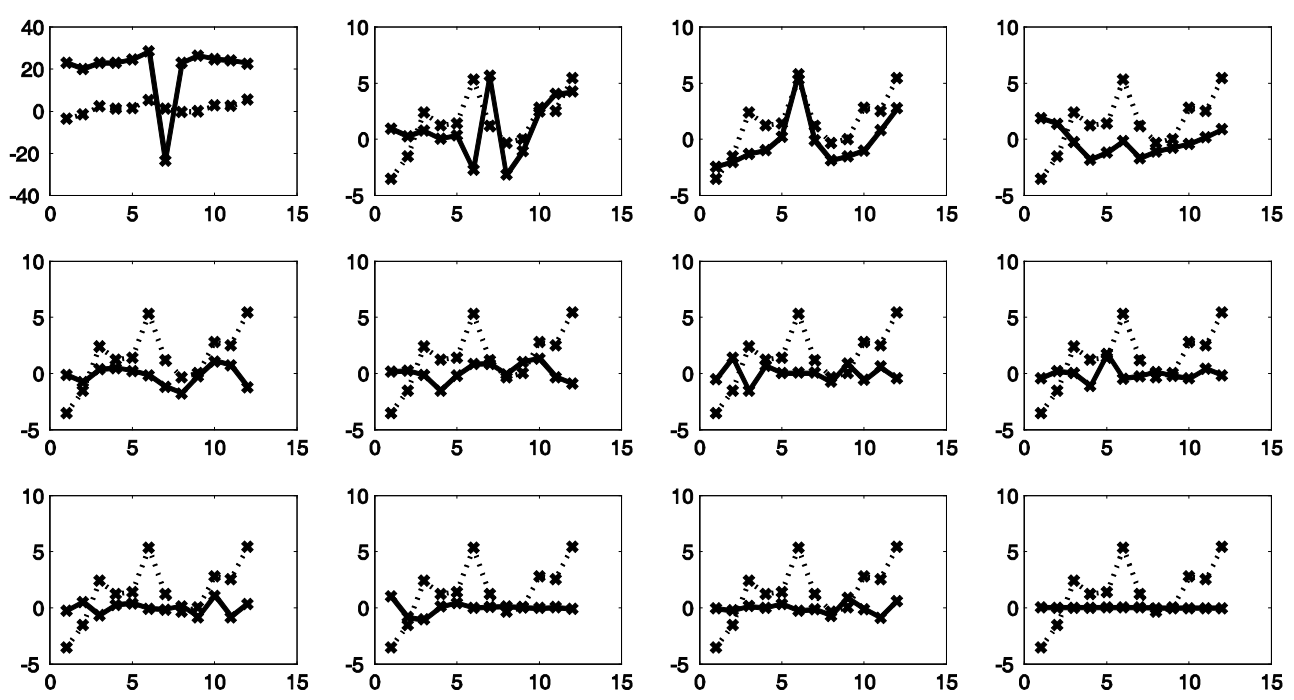

Figure 2: Mean currency excess returns of forward discount and currency momentum currency portfolios vs their principal components. This graph is organized as follows. The points connected by the straight line represent the covariances of the forward discount (portfolios 1 to 6) and currency momentum (portfolios 7 to 12) sorted currency portfolio returns with one of the 12 principal components. The points around the dashed line are the respective mean currency excess returns. The upper left picture in the first line displays the relation of covariances with the first principal component and average currency returns. The picture to the lower right gives the respective graphs for the $12^{\text {th }}$ principal component. 

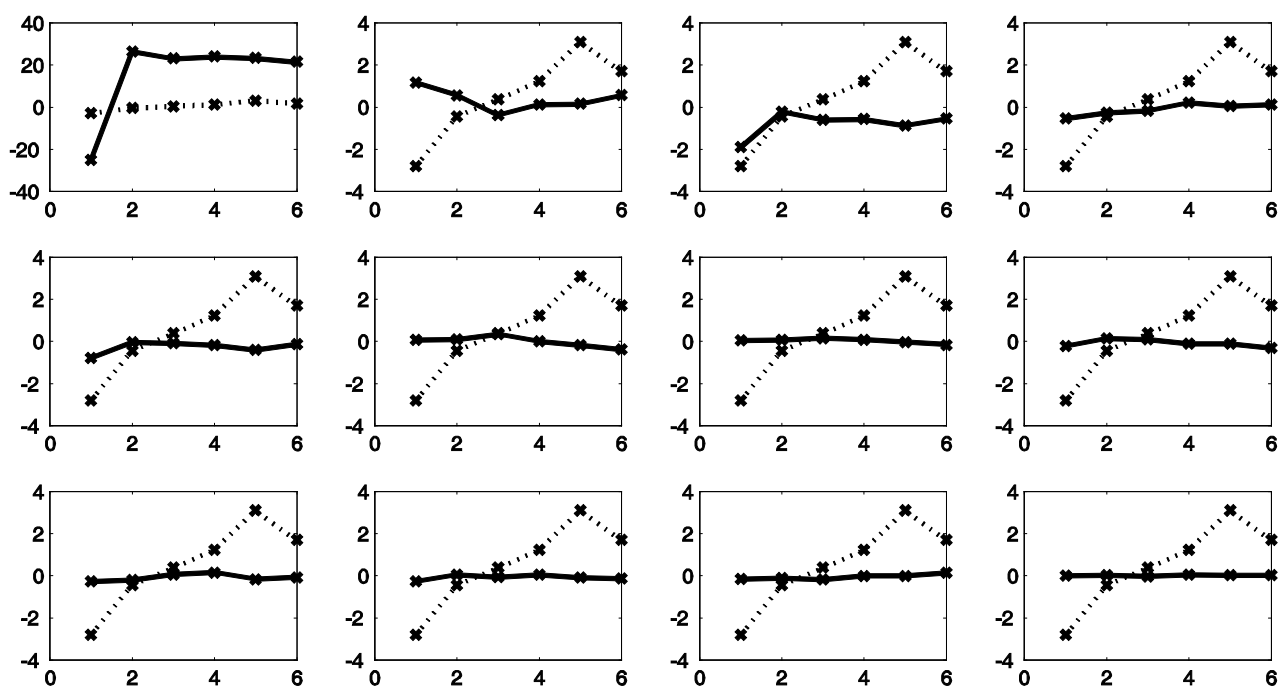

Figure 3: Mean excess returns on stock market momentum sorted portfolios vs covariances of these returns with principal components of 12 forward discount and currency momentum sorted currency portfolios. The points connected by the straight line represent the covariances of the stock market momentum sorted currency portfolio returns with one of the 12 principal components obtained from the 12 forward discount and currency momentum sorted portfolios. The points around the dashed line are the respective mean currency excess returns. The upper left picture in the first line displays the relation of covariances with the first principal component and average currency returns. The picture to the lower right gives the graph for the $12^{\text {th }}$ principal component 


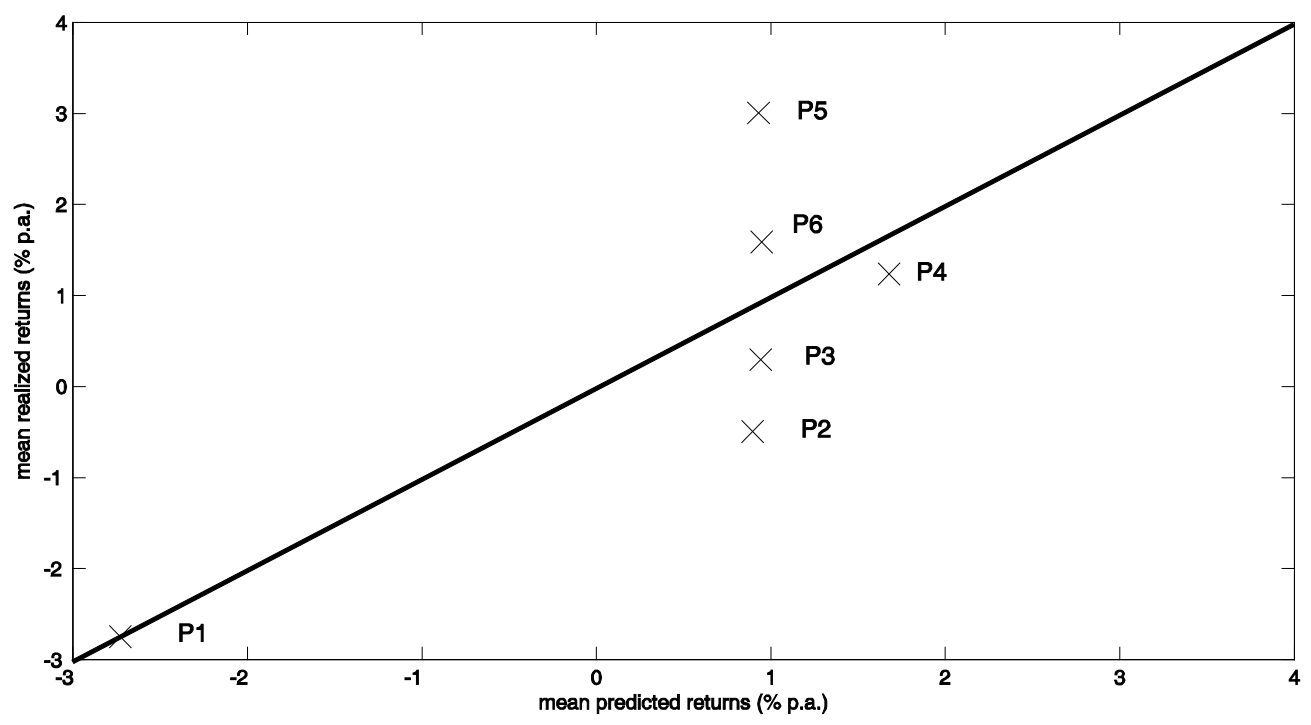

Figure 4: Fit of Lustig et al. two-factor model when confronted with six stock market momentum based currency portfolio returns. The vertical axis indicates mean realized returns, the horizontal axis mean predicted returns. All returns are in percentage points p.a. Portfolio 1 (P1) is the portfolio consisting of past stock market lose currencies while past stock market winner currencies are allocated to portfolio 6 . The straight line represents the $45^{\circ}$ line. 

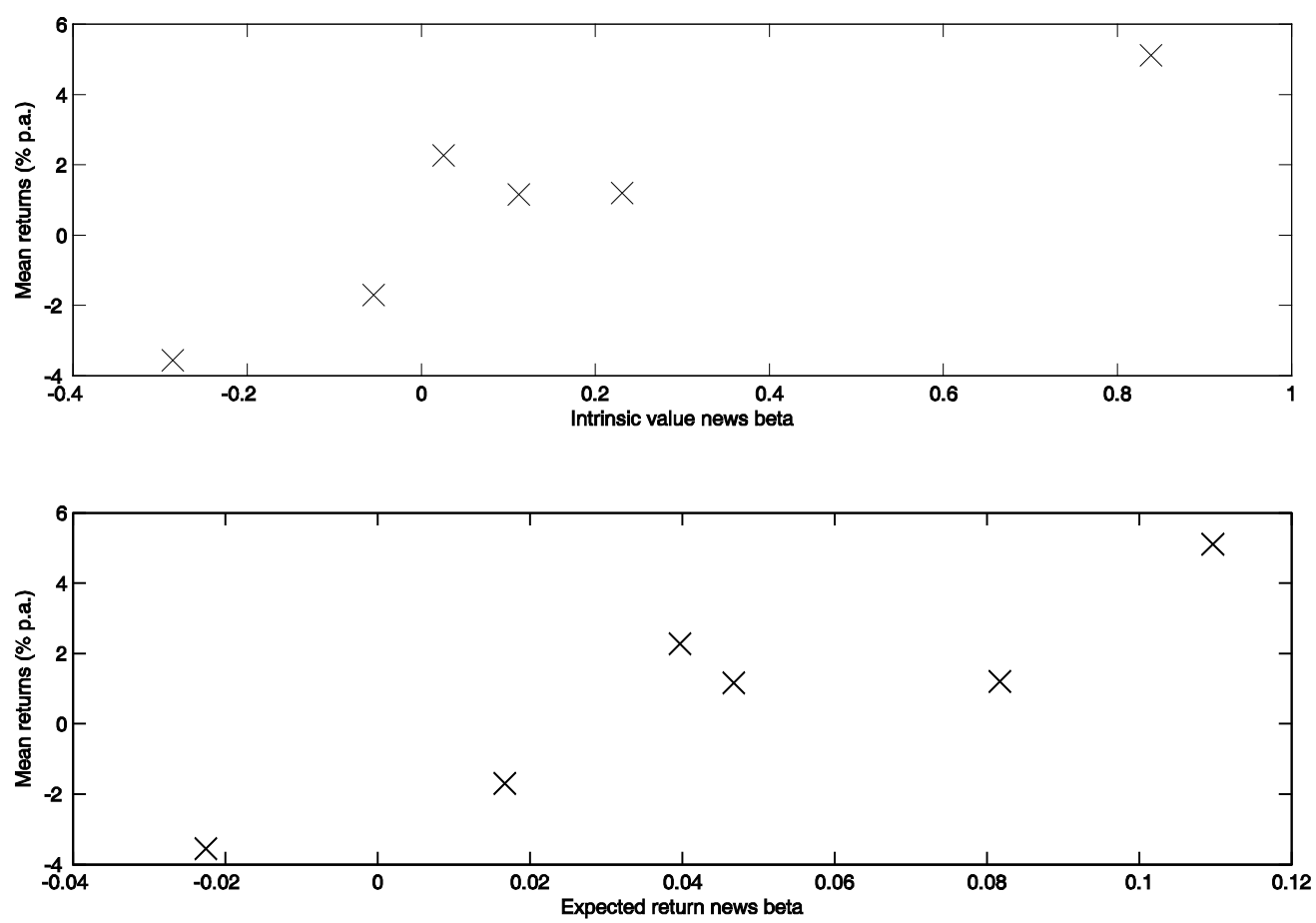

Figure 5: Mean excess returns on forward discount sorted currency portfolios and betas of their temporary and permanent components' sensitivity to the Lustig et al. (2009) high-minuslow factor 

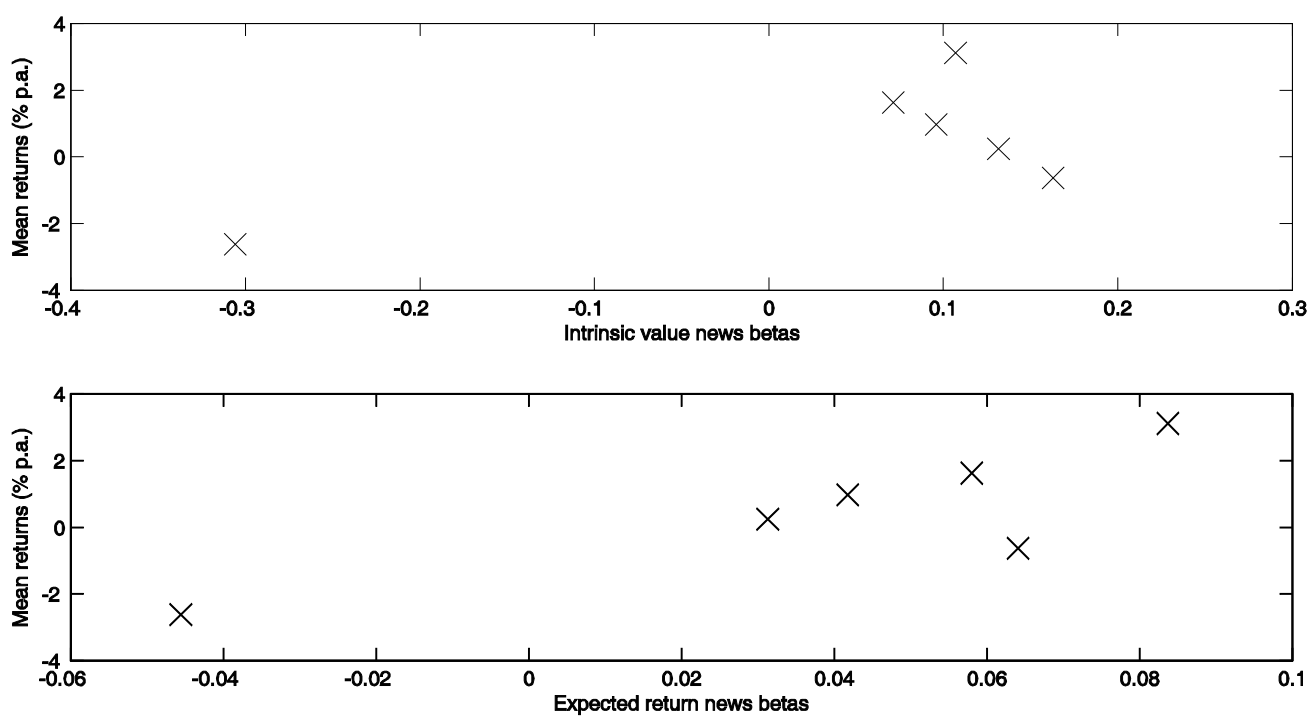

Figure 6: Mean excess returns on stock market momentum sorted currency portfolios and betas of their temporary and permanent components' sensitivity to the Lustig et al. (2009) high-minus-low factor 


\section{Appendix}

\section{A1 Currency portfolios formed according to 6-6 momentum}

The following table reports descriptive statistics of currency portfolios sorted according to 6-6 stock market momentum examined by Jagadeesh and Titman (1993), i.e. currency portfolio returns as of November 1983 depend on past, cumulated foreign stock market returns from December 1982 to May 1983. The sample period ranges from November 1983 to May 2009. All moments are reported in percentage points per annum. Portfolio 1 contains the currencies from stock market loser countries, while portfolio 6 consists of the stock market winner currencies. Table A1 presents excess returns net of transaction costs of a short position in portfolio 1 and long positions in all of the other currency portfolios. Panel A gives the descriptive statistics for a sample of developed and emerging markets, panel B reports the corresponding figures for a sample of developed countries only.

Similar to the 12-2 stock market momentum sorted currency portfolios, past stock market winners signal an appreciation of their currency which does not seem to be driven by the respective currency portfolio's forward discounts. High, cumulated past stock market returns signal not only currently high stock market but also excess returns on currencies. This finding holds after taking account of transaction costs. 
Table A1: Descriptive statistics of stock market momentum sorted currency portfolios

\begin{tabular}{|c|c|c|c|c|c|c|c|c|c|c|c|}
\hline \multirow[t]{3}{*}{ Portfolio } & $\overline{11}$ & 2 & 3 & 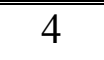 & 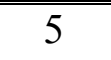 & $\overline{c 6}$ & 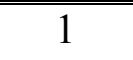 & 2 & 3 & 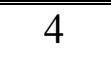 & 5 \\
\hline & \multicolumn{6}{|c|}{ Panel A: All countries } & \multicolumn{5}{|c|}{ Panel B: Developed countries } \\
\hline & \multicolumn{6}{|c|}{ Spot exchange rate changes } & \multicolumn{5}{|c|}{ Spot exchange rate changes } \\
\hline Mean & 1.25 & 0.76 & 0.50 & -1.76 & -1.97 & -1.47 & -0.14 & 0.69 & -1.40 & -3.00 & -3.10 \\
\hline STD & 9.36 & 9.17 & 8.82 & 8.47 & 8.21 & 8.29 & 10.06 & 9.95 & 9.88 & 9.66 & 9.4 \\
\hline \multicolumn{7}{|c|}{ Forward discounts } & \multicolumn{5}{|c|}{ Forward discounts } \\
\hline Mean & 1.84 & 1.86 & 1.23 & 1.36 & 1.94 & 1.27 & 0.74 & 0.69 & 0.60 & 0.69 & 0.42 \\
\hline STD & 1.73 & 1.02 & 1.58 & 1.29 & 1.57 & 1.24 & 0.94 & 0.82 & 0.84 & 0.76 & 0.8 \\
\hline
\end{tabular}

\begin{tabular}{cccccccccccc}
\hline & \multicolumn{4}{c}{ Stock returns } & \multicolumn{4}{c}{ Stock returns } \\
Mean & 6.47 & 7.94 & 11.50 & 13.70 & 12.65 & 17.11 & 8.54 & 7.76 & 11.81 & 13.58 & 14.76 \\
STD & 23.99 & 20.11 & 19.98 & 22.28 & 20.15 & 23.10 & 19.81 & 18.85 & 19.31 & 19.82 & 20.53
\end{tabular}

Excess returns

without bid/ask spreads

$\begin{array}{cccccccccccc}\text { Mean } & 0.59 & 1.11 & 0.73 & 3.12 & 3.91 & 2.74 & 0.89 & 0.00 & 2.00 & 3.70 & 3.52 \\ \text { STD } & 9.51 & 9.21 & 8.98 & 8.63 & 8.65 & 8.33 & 10.12 & 10.07 & 9.94 & 9.75 & 9.61 \\ \text { SR } & 0.06 & 0.12 & 0.08 & 0.36 & 0.45 & 0.33 & 0.09 & 0.00 & 0.20 & 0.38 & 0.37\end{array}$

Excess returns

without bid/ask spreads

$\begin{array}{llll}0.00 & 2.00 & 3.70 & 3.52\end{array}$

\begin{tabular}{ccccccccccccc}
\hline & \multicolumn{4}{c}{ Excess returns with bid/ask spreads } & \multicolumn{4}{c}{ Excess returns with bid/ask spreads } \\
Mean & -2.77 & -0.24 & -0.49 & 1.92 & 2.70 & 1.35 & -2.31 & -0.81 & 1.19 & 2.87 & 2.56 \\
STD & 9.55 & 9.22 & 8.98 & 8.65 & 8.61 & 8.38 & 10.11 & 10.08 & 9.96 & 9.78 & 9.66 \\
SR & -0.29 & -0.03 & -0.05 & 0.22 & 0.31 & 0.16 & -0.23 & -0.08 & 0.12 & 0.29 & 0.26
\end{tabular}

Notes: This table provides annualised, percentage point values of average spot exchange rate changes, forward discounts, stock returns, currency excess returns without taking account of transaction costs as well as currency returns computed with bid/ask spreads of 6-6 stock market momentum sorted currency portfolios. Panel A reports the characteristics of these portfolios for the sample of both developed and emerging markets. Panel B displays the corresponding values for a sample of developed countries only. These portfolios are rebalanced every month. "Mean" indicates the arithmetic average of the respective currency portfolio returns, "SD" the corresponding standard deviation and in the case of excess returns "SR" gives the Sharpe ratio, i.e. the ratio of mean returns and standard deviation. The sample period ranges from November 1983 to May 2009. 6-6 momentum means that e.g. foreign currency returns in November 1983 are allocated to portfolios according to the cumulated monthly stock market returns of a particular country in the period from December 1982 to June 1983. Portfolio 1 always the currencies from countries with lowest, portfolio 6 the currencies from countries with highest stock market momentum returns. 


\section{A2 Reconstruction of Lustig et al. (2009) currency portfolios}

The sample periods of the stock market momentum based formation of currency portfolios do not necessarily coincide with the sample periods of forward discount or currency momentum sorted currency portfolios in Lustig et al. (2009). In order to allow a direct comparison between these different currency portfolio sorts, I reconstruct the forward discount and currency momentum currency portfolios for the sample periods used in the stock market momentum sorting of foreign currencies.

Excess returns on forward discount sorted currency portfolios at time $t+1$ are allocated to portfolios according to the forward discount at time t. Excess returns on currency momentum sorted currency portfolios at time $\mathrm{t}+1$ are allocated to portfolios based on currency excess returns at time $t$. These portfolios are rebalanced every month. The sample period ranges from November 1983 to May 2009,

The respective descriptive statistics confirm the main results by Lustig et al. (2009). High excess returns on foreign currencies are associated with high forward discounts or high currency returns in the previous periods. 
Table A2: Descriptive statistics of forward discount

and currency momentum sorted currency portfolios

\begin{tabular}{|c|c|c|c|c|c|c|c|c|c|c|c|c|}
\hline \multirow[t]{4}{*}{ Portfolio } & 1 & 2 & 3 & 4 & 5 & 6 & 1 & 2 & 3 & 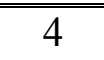 & 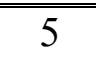 & 6 \\
\hline & \multicolumn{6}{|c|}{ Panel A: Forward discount sorted } & \multicolumn{6}{|c|}{ Panel B: Currency momentum sorted } \\
\hline & \multicolumn{6}{|c|}{ Excess returns } & \multicolumn{6}{|c|}{ Excess returns } \\
\hline & \multicolumn{6}{|c|}{ without bid/ask spreads } & \multicolumn{6}{|c|}{ without bid/ask spreads } \\
\hline Mean & -2.47 & -0.80 & 3.22 & 2.24 & 2.81 & 8.23 & -3.19 & 0.91 & 1.13 & 3.85 & 3.64 & 7.12 \\
\hline STD & 8.44 & 7.69 & 8.21 & 8.51 & 8.57 & 11.06 & 9.60 & 8.78 & 9.10 & 8.94 & 8.94 & 9.00 \\
\hline SR & -0.29 & -0.10 & 0.39 & 0.26 & 0.33 & 0.74 & -0.33 & 0.10 & 0.12 & 0.43 & 0.41 & 0.79 \\
\hline
\end{tabular}

Correlation with original

Lustig et al. (2009) portfolios

$\begin{array}{llllll}0.95 & 0.84 & 0.84 & 0.82 & 0.86 & 0.90\end{array}$

Excess returns with bid/ask spreads

$\begin{array}{ccccccc}\text { Mean } & -3.51 & -1.60 & 2.30 & 1.17 & 1.41 & 5.23 \\ \text { STD } & 8.49 & 7.72 & 8.22 & 8.50 & 8.61 & 11.02 \\ \text { SR } & -0.41 & -0.21 & 0.28 & 0.14 & 0.16 & 0.47\end{array}$

Notes: This table presents excess returns on currency portfolios that are formed according to forward discounts, the difference between forward and spot exchange rate, and past currency returns following Lustig et al. (2009). Forward discount rate currency portfolios at time $t+1$ are based on forward discounts at time t. Currency momentum based portfolios at time $\mathrm{t}+1$ are formed according to currency excess returns at time $t$. These currency portfolios are built with respect to the countries' sample periods used in the formation of stock market momentum based currency portfolios. Panel A gives the excess returns on forward discount sorted currency portfolios without taking account of bid/ask spreads, the correlation with the original Lustig et al. (2009) forward discount rate currency portfolios and excess returns net of transaction costs assuming a short position in portfolio 1, the portfolio comprised of currencies with lowest forward discount, and long positions in all other currencies. Panel B gives descriptive statistics of the excess returns on currency momentum sorted portfolios. The original Lustig et al. (2009) currency momentum portfolios are not publicly available and it is not clear how to incorporate transaction costs for this portfolio sort. Hence there is only data on excess returns without bid/ask spreads. The average returns (mean), standard deviations (SD) and Sharpe ratios (SR) are in percentage points per annum. The sample period ranges from November 1983 to May 2009. 
A3 Predictability of stock market momentum sorted currency portfolios returns: Macroeconomic variables

Here, I assess if the macroeconomic predictive variables proposed by Chen, Roll and Ross (1986) predict returns on stock market momentum sorted currency portfolios one month ahead. These variables are the yield spread between a 10-year government bond and the 3month treasury bill (term spread, TS), the spread between Baa rated long-term corporate bonds and the long-term government bond (default spread, DS) and changes in monthly and annual industrial production (MIP, AIP) respectively. Data on a monthly index of industrial production can be obtained from the Federal Reserve Bank of St Louis. The interest rate data is from the Federal Reserve Board of Governors, Table H15.

Table A3 reports estimates from regressions of monthly excess returns on the 12-2 stock market momentum sorted currency portfolios on these predictive variables one month ahead, i.e.

$$
\phi_{t, t+1}^{i}=\mu+\beta^{i} x_{t}+\varepsilon_{t, t+1}^{i}
$$

with $\phi_{t, t+1}^{i}$ the monthly currency excess return on currency portfolio $i$ and $x_{t}$ denotes one of the forecasting variables. The sample period ranges from November 1983 to May 2009. Newey - West (Newey and West (1987)) corrected t-statistics are below the estimates in parenthesis. An asterisk indicates significance at the $95 \%$ confidence level. $R^{2}$ denotes the adjusted $R^{2}$.

The regression results are easily summarized. None of the macroeconomic variables captures the time series variation in the stock market momentum sorted currency portfolio returns. 
Table A3: Predictability of stock market momentum

currency portfolio returns

\begin{tabular}{|c|c|c|c|c|c|c|}
\hline Portfolios & 1 & 2 & 3 & 4 & 5 & 6 \\
\hline \multicolumn{7}{|c|}{ Panel A } \\
\hline MIP & $-{ }_{(-0.15)}^{0.05}$ & $\begin{array}{c}-0.18 \\
(-0.60)\end{array}$ & $\begin{array}{c}-0.38 \\
(-1.67)\end{array}$ & -0.15 & $\begin{array}{c}-0.04 \\
(-0.16)\end{array}$ & $\begin{array}{c}-0.03 \\
(-0.15)\end{array}$ \\
\hline$R^{2}$ & 0.00 & 0.00 & 0.00 & 0.00 & 0.00 & 0.00 \\
\hline \multicolumn{7}{|c|}{ Panel B } \\
\hline AIP & $-\underset{(-0.15)}{0.01}$ & -0.03 & $-\underset{(-1.20)}{0.05}$ & $\begin{array}{c}-0.03 \\
(-0.75)\end{array}$ & -0.00 & $\begin{array}{c}-0.05 \\
(-1.36)\end{array}$ \\
\hline$R^{2}$ & 0.00 & 0.00 & 0.00 & 0.00 & 0.00 & 0.00 \\
\hline \multicolumn{7}{|c|}{ Panel C } \\
\hline $\mathrm{TS}$ & $-\underset{(-1.09)}{0.00}$ & $\begin{array}{c}0.00 \\
(1.05)\end{array}$ & $\begin{array}{c}-0.00 \\
(-0.05)\end{array}$ & $\begin{array}{l}0.00 \\
(0.96)\end{array}$ & $\begin{array}{l}0.00 \\
(1.77)\end{array}$ & $\underset{(1.20)}{0.00}$ \\
\hline$R^{2}$ & 0.00 & 0.00 & 0.00 & 0.00 & 0.01 & 0.00 \\
\hline \multicolumn{7}{|c|}{ Panel D } \\
\hline DS & $\begin{array}{c}-0.00 \\
(-1.04)\end{array}$ & $\begin{array}{l}0.00 \\
(0.28)\end{array}$ & $\begin{array}{l}0.00 \\
(0.74)\end{array}$ & $\begin{array}{l}0.00 \\
(0.73)\end{array}$ & $\begin{array}{l}0.00 \\
(0.15)\end{array}$ & $\begin{array}{l}0.00 \\
(0.50)\end{array}$ \\
\hline$R^{2}$ & 0.00 & 0.00 & 0.00 & 0.00 & 0.00 & 0.00 \\
\hline
\end{tabular}

Notes: This table reports estimates from one month ahead regressions of monthly excess returns on 12-2 stock market momentum sorted currency portfolios on predictive, macroeconomic variables advocated by Chen et al. (1986). These variables are: The yield spread between a 10-year government bond and the 3-month treasury bill (term spread, TS), the spread between Baa rated long-term corporate bonds and the long-term government bond (default spread, DS) and changes in monthly and annual industrial production (MIP, AIP) respectively.

The estimates are obtained from the following regression

$$
\phi_{t, t+1}^{i}=\mu+\beta^{i} x_{t}+\varepsilon_{t, t+1}^{i}
$$

with $\phi_{t, t+1}^{i}$ the monthly currency excess return on currency portfolio $i$ and $x_{t}$ denotes one of the forecasting variables. The sample period ranges from November 1983 to May 2009. Newey - West (Newey and West (1987)) corrected t-statistics are below the estimates in parenthesis. An asterisk indicates significance at the $95 \%$ confidence level. $R^{2}$ denotes the adjusted $R^{2}$. 


\section{A4 Currency momentum factors}

The Lustig el al. (2009) $H M L^{F X}$ factor captures the cross-sectional variation both in forward discount and currency momentum sorted currency portfolio returns but is unable to explain average excess returns on stock market momentum sorted currency portfolios. This section briefly summarizes the performance of a model that uses the currency momentum sorted currency portfolios to construct the two-factor analogue to the Lustig et al. (2009) model. Instead of $H M L^{F X}$, this section regards the return difference between high and low currency momentum portfolios, $C H M L^{F X}$, together with the average return over all currency momentum portfolios, $R^{F X}$, as pricing factors. These two factors are confronted with the six 12-2 stock market momentum sorted currency portfolio returns. The risk price estimates as well as time series regression evidence is presented in table A5. The main results are very similar to the ones obtained with the $H M L^{F X}$ factor. The cross-sectional estimates in panel A of table A5 suggest that this pricing model based on currency momentum factors explains about two thirds of average returns on stock market momentum sorted currency portfolios. The time series estimates of panel B show that also about 60 to 70 percent of the time series variation in these returns is explained by that model. However, the Gibbons, Ross and Shanken (1989) test shows that pricing errors are not significantly different from zero. In addition, figure A1 presents the cross-sectional fit of the model. As in the case of the Lustig et al. (2009) two factor model, mean predicted returns for portfolio 2 to 6 are almost identical. This finding highlights the relatively poor cross-sectional fit of the model. 
Table A4: Pricing stock market momentum currency portfolio returns

with currency momentum factors

\begin{tabular}{|c|c|c|c|c|}
\hline \multicolumn{5}{|c|}{ Panel A: Risk price estimates } \\
\hline$\lambda_{R F X}$ & $\lambda_{\text {CHMLFX }}$ & $R^{2}$ & mape & mspe \\
\hline$-{ }_{(-0.43)}^{0.74}$ & $\begin{array}{l}7.55 \\
(1.62)\end{array}$ & 0.67 & 0.82 & 1.12 \\
\hline \multicolumn{5}{|c|}{ Panel B: Time series estimates } \\
\hline & $\alpha^{i}$ & $\beta_{R F X}^{i}$ & $\beta_{\text {CHMLFX }}^{i}$ & $R^{2}$ \\
\hline P1 & $\begin{array}{c}-0.59 \\
(-0.39)\end{array}$ & $\frac{-0.26}{(-1.15)}$ & $-\underset{(-4.57)}{0.43}$ & 0.62 \\
\hline $\mathrm{P} 2$ & $-\begin{array}{r}3.20 \\
(-3.28)\end{array}$ & $\begin{array}{l}0.92 \\
(10.71)\end{array}$ & $\begin{array}{l}0.23 \\
(7.06)\end{array}$ & 0.76 \\
\hline P3 & $-\underset{(-1.76)}{1.96}$ & $\begin{array}{l}0.75 \\
(6.00)\end{array}$ & $\begin{array}{l}0.21 \\
(5.40)\end{array}$ & 0.62 \\
\hline P4 & $-\frac{1.24}{(-1.35)}$ & $\begin{array}{l}0.76 \\
(8.33)\end{array}$ & $\begin{array}{l}0.23 \\
(7.11)\end{array}$ & 0.71 \\
\hline P5 & $\begin{array}{l}0.68 \\
(0.71)\end{array}$ & $\begin{array}{l}\underset{(8.35)}{0.75} \\
0\end{array}$ & $\begin{array}{l}0.22 \\
(6.03)\end{array}$ & 0.68 \\
\hline P6 & $-\underset{(-0.62)}{0.55}$ & $\begin{array}{l}0.69 \\
(5.84)\end{array}$ & $\begin{array}{l}0.21 \\
(5.48)\end{array}$ & 0.67 \\
\hline
\end{tabular}

Notes: Panel A of this table presents risk price estimates from a two stage Fama-MacBeth regression of excess returns on stock market momentum sorted currency portfolios on the two risk factors constructed from currency momentum sorted currency portfolios in analogue to the two-factor model of Lustig et al. (2009). The two factors are the average return across six currency return sorted currency portfolios, $R^{F X}$, and the return difference between the high and low currency return sorted currency portfolios, $C H M L^{F X}$. Shanken (1992) corrected t-statistics appear below the estimates in parenthesis. Risk price estimates, mean absolute (mape) as well as mean squared pricing errors (mspe) are reported in percentage points per annum.

Panel B gives the estimates from the first stage of the Fama-MacBeth regression, i.e. the time series regressions of currency portfolio returns on the factors. Newey and West (1987) corrected t-statistics appear below the estimates in parenthesis.

The sample period ranges from November 1983 to May 2009. 


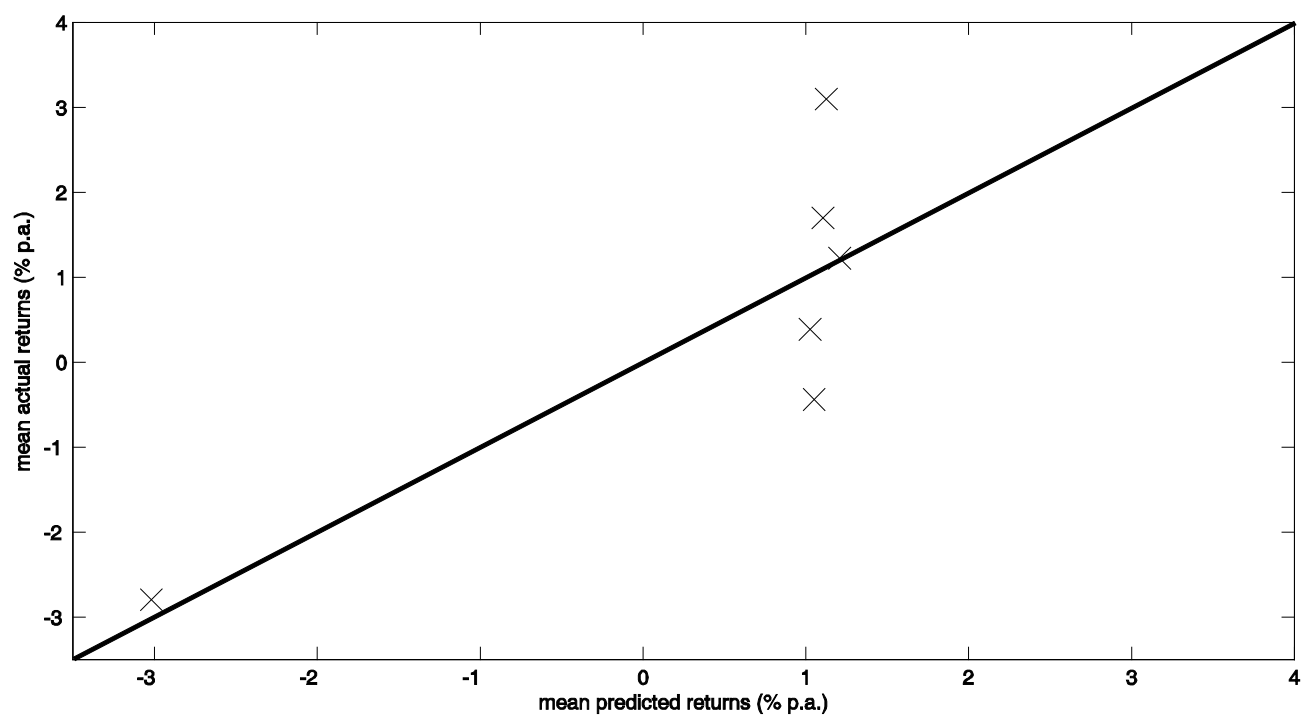

Figure A1: Fit of currency momentum based two-factor model when confronted with six 12-2 stock market momentum sorted currency portfolio returns. The vertical axis indicates mean realized returns, the horizontal axis mean predicted returns. All returns are in percentage points p.a. Portfolio $1(\mathrm{P} 1)$ is the portfolio consisting of past stock market loser currencies while past stock market winner currencies are allocated to portfolio 6 . The straight line represents the $45^{\circ}$ line. 


\section{A5 Conditional pricing model}

The time series evidence conveys the notion that the stock market momentum sorted currency portfolio returns are predictable by the TED spread. Hence, we could use the TED spread as signalling variable and consider a conditional cross-sectional model. Rearranging equation (8) from the main text of the paper then leads to

$$
0=E\left(z_{t} m_{t+1} \phi_{t+1}^{i}\right)
$$

with $z_{t}$ the signalling variable, here the TED spread. However, Lewellen and Nagel (2006) question the usefulness of conditional models especially because they typically fail in the time series. As the reformulation into a conditional model also results in a higher number of factors but I regard only six currency portfolios as test assets, the empirical evidence is further flawed. Table A4 gives an example for the cross-sectional and time series performance of a conditional model that works best in this context. To keep the number of factors at a minimum, I assume that the stochastic discount factor comprises only the Lustig et al. (2009) high-minus-low factor, $H M L^{F X}$. The first stage of the Fama-MacBeth (1973) estimate equations then takes the following form:

$$
\phi_{t+1}^{i}=\alpha^{i}+\beta_{H M L F X}^{i} H M L_{t+1}^{F X}+\beta_{T E D}^{i} T E D_{t}+\beta_{T E D x H M L}^{i} T E D_{t} \times H M L_{t+1}^{F X} \varepsilon_{t}^{i}
$$

Second stage:

$$
\phi_{t}^{i}=\hat{\beta}_{H M L X}^{i} \lambda_{H M L F X}+\hat{\beta}_{T E D}^{i} \lambda_{T E D}+\hat{\beta}_{T E D x H M L}^{i} \lambda_{T E D x H M L}+v_{t}^{i}, \forall t
$$

Panel A of table A4 gives the risk price estimates while panel B highlights the time series performance of the model. Differences in the lagged TED spread are marginally priced in the six currency portfolio returns. Even though pricing errors and the measure of fit seem to be considerably improved compared to the cross-sectional pricing exercises reported in the main body of the paper, this finding comes at the cost of a poor time series performance. Not only are two of the six time series pricing errors individually significantly different from zero, the Gibbons, Ross and Shanken (1989) test also indicates that the p-value for the null of all pricing errors jointly being zero is 0.0 . In addition, compared to the performance of the Lustig et al. (2009) model only little of the time series variation in the currency portfolios formed according to stock market momentum is explained by the conditional model. Hence, this model does not solve the difficulties to price the excess returns on stock market momentum based currency portfolios 
Table A5: Conditional pricing model and stock market momentum foreign currency returns

\begin{tabular}{|c|c|c|c|c|c|}
\hline \multicolumn{6}{|c|}{ Panel A: Cross-sectional performance } \\
\hline$\lambda_{\text {HMLFX }}$ & $\lambda_{T E D}$ & $\lambda_{\text {TEDxHML }}$ & $R^{2}$ & mape & mspe \\
\hline$-{ }_{(-0.18)}^{1.70}$ & $\begin{array}{l}0.80 \\
(1.93)\end{array}$ & $\begin{array}{l}0.03 \\
(0.70)\end{array}$ & 0.74 & 0.76 & 0.88 \\
\hline \multicolumn{6}{|c|}{ Panel B: Time series performance } \\
\hline & $\alpha^{i}$ & $\beta_{H M L F X}^{i}$ & $\beta_{T E D}^{i}$ & $\beta_{\text {TEDxHML }}^{i}$ & $R^{2}$ \\
\hline $\mathrm{P} 1$ & $\begin{array}{l}-3.75 \\
(-1.02)\end{array}$ & $\begin{array}{l}-0.36 \\
(-2.44)\end{array}$ & $-\underset{(-1.28)}{2.07}$ & $-\underset{(-0.99)}{45.74}$ & 0.09 \\
\hline $\mathrm{P} 2$ & $\underset{(1.31)}{4.15}$ & $\underset{(0.54)}{0.05}$ & $\underset{(1.81)}{2.74}$ & $-\underset{(-0.54)}{21.89}$ & 0.03 \\
\hline P3 & $\begin{array}{l}0.39 \\
(0.13)\end{array}$ & $\begin{array}{l}0.07 \\
(0.88)\end{array}$ & $\begin{array}{l}0.38 \\
(0.24)\end{array}$ & -11.60 & 0.00 \\
\hline $\mathrm{P} 4$ & $\underset{(1.53)}{4.74}$ & $\begin{array}{l}0.00 \\
(0.00)\end{array}$ & $\begin{array}{l}1.95 \\
(1.35)\end{array}$ & $-\underset{(-0.70)}{24.11}$ & 0.01 \\
\hline P5 & 10.38 & -0.05 & $\begin{array}{l}3.74 \\
(2.93)\end{array}$ & -32.95 & 0.04 \\
\hline P6 & $\begin{array}{l}5.94 \\
(2.16)\end{array}$ & $\begin{array}{l}0.03 \\
(0.47)\end{array}$ & $\begin{array}{l}2.39 \\
(1.96)\end{array}$ & $\begin{array}{l}5.18 \\
(0.18)\end{array}$ & 0.01 \\
\hline \multicolumn{6}{|c|}{$\begin{array}{l}\text { Notes: Panel A of this table reports risk price estimates of a conditional model's beta representation that features } \\
\text { the TED spread, the spread between a Treasury bill rate and the Eurodollar deposit rate, as conditioning variable }\end{array}$} \\
\hline \multicolumn{6}{|c|}{$\begin{array}{l}\text { and regards the Lustig et al. (2009) } H M L^{F X} \text { factor as sole risk factor. The risk price estimates are obtained from } \\
\text { a two-stage Fama-Mac Beth regression (Fama and MacBeth (1973)). The first stage time series estimates are } \\
\text { presented in panel B of this table. The sample period ranges from November } 1983 \text { to May 2009. T-statistics of } \\
\text { the risk price estimates in parenthesis are Shanken (1992) corrected. T-statistics of the time series estimates are } \\
\text { Newey-West (Newey and West (1987)) corrected. }\end{array}$} \\
\hline
\end{tabular}




\section{A.6 Currency returns and "winner-minus-loser" factor}

This section assesses whether risk factors constructed from the excess returns on stock market momentum sorted currency portfolios explain the cross-sectional differences in the Lustig et al. (2009) forward discount and currency momentum sorted currency portfolios. Following Lustig et al. (2009), I consider a two factor model comprised of the average currency excess returns, $R^{F X}$, and the return difference between the stock market winner and loser currency portfolios, $W M L^{F X}$.

The cross-sectional pricing equation is

$$
E_{t}\left(\phi_{t}^{i}\right)=\hat{\beta}_{R F X}^{i} \lambda_{R F X}+\hat{\beta}_{W M L F X}^{i} \lambda_{W M L F X}
$$

with RFX again indicating the average currency portfolio excess return, the dollar factor in the terms of Lustig et al. (2009), and WMLFX indicating the winner-minus-loser currency risk factor, $W M L^{F X}$. Table A.6 gives the corresponding risk price estimates for a sample of the forward discount sorted currency portfolios (panel A), currency momentum sorted currency portfolios (panel B) and the currency portfolios of both sorts jointly (panel C). At first glance, panel A leaves the impression that the $W M L^{F X}$ factor explains the cross-sectional dispersion in forward discount sorted currency returns. The estimated risk price, however, is three times too large. Panel B shows that the model does a poor job in rationalizing the currency momentum portfolio returns. Panel $\mathrm{C}$ then presents the estimates obtained when considering forward discount and currency momentum jointly as test assets. Still the fit of the model is relatively poor even though the winner-minus-loser factor is significantly priced. Its risk price is still too high, i.e. about twice as high as the mean return on the winner-minusloser factor.

Table A.7 provides details of the first stage Fama-MacBeth (1973) time series regression

$$
\phi_{t}^{i}=\alpha^{i}+\beta_{R F X}^{i} R_{t}^{F X}+\beta_{W M L F X}^{i} W M L_{t}^{F X}+\varepsilon_{t}^{i}
$$

with Newey-West (Newey and West (1987)) corrected t-statistics in parenthesis. Irrespective if we regard excess returns on forward discount or currency momentum sorted currency portfolios, the two-factor model explains between 60 to 75 percent of their time series variation. But pricing errors seem to be large and not only individually but also jointly significant.

Both the cross-sectional and the time series evidence presented in this subsection resemble the outcomes from attempts to price the stock market momentum currency portfolios with factors constructed from forward discount portfolios. The flipside exercise, using factors constructed from stock market momentum currency portfolio returns to explain forward discount and 
currency momentum sorted currency returns, reveals the same pattern. A relatively big proportion of the time series variation is explained by the model but the cross-sectional performance is relatively poor. 
Table A.6: Cross-sectional performance of two-factor model Factors extracted from stock market momentum currency portfolios

\begin{tabular}{|c|c|c|c|c|}
\hline \multicolumn{5}{|c|}{ Panel A: Forward discount sorted portfolio returns } \\
\hline$\lambda_{R F X}$ & $\lambda_{\text {WMLFX }}$ & $R^{2}$ & mape & mspe \\
\hline$-\underset{(-1.85)}{2.89}$ & $\underset{(2.92)}{13.36}$ & 0.81 & 0.86 & 0.96 \\
\hline \multicolumn{5}{|c|}{ Panel B: Currency momentum sorted portfolio returns } \\
\hline$\lambda_{R F X}$ & $\lambda_{W M L F X}$ & $R^{2}$ & mape & mspe \\
\hline $1_{(1.15)}^{1.75}$ & $\begin{array}{l}0.96 \\
(0.22)\end{array}$ & -0.22 & 2.51 & 5.18 \\
\hline \multicolumn{5}{|c|}{ Panel C: forward discount and currency momentum portfolio returns } \\
\hline$\lambda_{R F X}$ & $\lambda_{W M L F X}$ & $R^{2}$ & mape & mspe \\
\hline$-\underset{(-0.70)}{0.97}$ & $\underset{(2.11)}{8.50}$ & 0.22 & 1.59 & 4.04 \\
\hline
\end{tabular}

Notes: This table presents risk price estimates from a two stage Fama-MacBeth regression of excess returns on 6 forward discount (panel A), 6 currency momentum (panel B) and 12 forward discount or currency momentum sorted currency portfolios on two risk factors constructed from stock market momentum sorted currency portfolio returns in analogue to Lustig et al. (2009), i.e. the average return across the stock market momentum sorted currency portfolios, $R^{F X}$, and the return difference between the past winner and loser stock market sorted currency portfolios, $W M L^{F X}$. Shanken (1992) corrected t-statistics appear below the estimates in parenthesis. Risk price estimates, mean absolute (mape) as well as mean squared pricing errors (mspe) are reported in percentage points per annum. The sample period ranges from November 1983 to May 2009. 
Table A.7: Time series performance of WML model

\begin{tabular}{|c|c|c|c|c|}
\hline \multicolumn{5}{|c|}{ Panel A: Forward discount sorted portfolio returns } \\
\hline & $\alpha^{i}$ & $\beta_{R F X}^{i}$ & $\beta_{W M L F X}^{i}$ & $R^{2}$ \\
\hline $\mathrm{P} 1$ & $\underset{(1.89)}{2.03}$ & $\underset{(-7.72)}{-0.81}$ & $-\underset{(-6.30)}{0.22}$ & 0.72 \\
\hline $\mathrm{P} 2$ & $-\underset{(-2.61)}{2.59}$ & $\begin{array}{l}0.85 \\
(9.76)\end{array}$ & $\begin{array}{l}0.14 \\
(5.60)\end{array}$ & 0.67 \\
\hline P3 & $\underset{(1.30)}{1.00}$ & $\begin{array}{l}0.79 \\
(8.58)\end{array}$ & $\underset{(8.11)}{0.22}$ & 0.75 \\
\hline P4 & $-\underset{(-0.18)}{0.17}$ & $\begin{array}{l}0.79 \\
(8.93)\end{array}$ & $\underset{(8.59)}{0.22}$ & 0.71 \\
\hline P5 & $\underset{(-0.15)}{-0.15}$ & $\begin{array}{l}0.73 \\
(9.66)\end{array}$ & $\underset{(10.10)}{0.26}$ & 0.74 \\
\hline P6 & $\begin{array}{l}3.01 \\
(1.84)\end{array}$ & $\begin{array}{c}0.29 \\
(1.43)\end{array}$ & $\underset{(6.41)}{0.48}$ & 0.63 \\
\hline
\end{tabular}

\begin{tabular}{|c|c|c|c|c|}
\hline \multicolumn{5}{|c|}{ Panel B: Currency momentum sorted portfolio returns } \\
\hline & $\alpha^{i}$ & $\beta_{R F X}^{i}$ & $\beta_{W M L F X}^{i}$ & $R^{2}$ \\
\hline P1 & $\begin{array}{l}3.09 \\
(2.64)\end{array}$ & $\frac{-0.32}{(-1.49)}$ & $-\frac{0.38}{(-4.55)}$ & 0.58 \\
\hline $\mathrm{P} 2$ & $-\underbrace{1.62}_{(-1.61)}$ & $\underset{(8.07)}{0.88}$ & $\underset{(6.94)}{0.18}$ & 0.65 \\
\hline P3 & $-\underbrace{1.46}_{(-1.67)}$ & $\begin{array}{l}0.97 \\
(12.71)\end{array}$ & $\underset{(10.34)}{0.22}$ & 0.77 \\
\hline P4 & $1_{(1.54)}$ & $\begin{array}{l}0.89 \\
(8.47)\end{array}$ & $\begin{array}{l}0.22 \\
(7.60)\end{array}$ & 0.72 \\
\hline P5 & $\begin{array}{l}0.88 \\
(0.92)\end{array}$ & $\underset{(6.33)}{0.62}$ & $\begin{array}{l}0.30 \\
(9.01)\end{array}$ & 0.68 \\
\hline P6 & $\begin{array}{l}3.95 \\
(3.64)\end{array}$ & $\underset{(5.91)}{0.66}$ & $\begin{array}{l}0.25 \\
(6.99)\end{array}$ & 0.58 \\
\hline
\end{tabular}

Notes: This table gives the estimates from the first stage of the Fama-MacBeth regression, i.e. the time series regressions of currency portfolio returns on the average return across the stock market momentum sorted currency portfolios, $R^{F X}$, and the return difference between the past winner and loser stock market sorted currency portfolios, $W M L^{F X}$. Newey and West (1987) corrected t-statistics appear below the estimates in parenthesis. $R^{2}$ denotes the adjusted $R^{2}$. 


\section{Swiss National Bank Working Papers published since 2004:}

2004-1 Samuel Reynard: Financial Market Participation and the Apparent Instability of Money Demand

2004-2 Urs W. Birchler and Diana Hancock: What Does the Yield on Subordinated Bank Debt Measure?

2005-1 Hasan Bakhshi, Hashmat Khan and Barbara Rudolf: The Phillips curve under state-dependent pricing

2005-2 Andreas M. Fischer: On the Inadequacy of Newswire Reports for Empirical Research on Foreign Exchange Interventions

2006-1 Andreas M. Fischer: Measuring Income Elasticity for Swiss Money Demand: What do the Cantons say about Financial Innovation?

2006-2 Charlotte Christiansen and Angelo Ranaldo: Realized Bond-Stock Correlation: Macroeconomic Announcement Effects

2006-3 Martin Brown and Christian Zehnder: Credit Reporting, Relationship Banking, and Loan Repayment

2006-4 Hansjörg Lehmann and Michael Manz: The Exposure of Swiss Banks to Macroeconomic Shocks - an Empirical Investigation

2006-5 Katrin Assenmacher-Wesche and Stefan Gerlach: Money Growth, Output Gaps and Inflation at Low and High Frequency: Spectral Estimates for Switzerland

2006-6 Marlene Amstad and Andreas M. Fischer: Time-Varying Pass-Through from Import Prices to Consumer Prices: Evidence from an Event Study with Real-Time Data

2006-7 Samuel Reynard: Money and the Great Disinflation

2006-8 Urs W. Birchler and Matteo Facchinetti: Can bank supervisors rely on market data? A critical assessment from a Swiss perspective

2006-9 Petra Gerlach-Kristen: A Two-Pillar Phillips Curve for Switzerland

2006-10 Kevin J. Fox and Mathias Zurlinden: On Understanding Sources of Growth and Output Gaps for Switzerland

2006-11 Angelo Ranaldo: Intraday Market Dynamics Around Public Information Arrivals

2007-1 Andreas M. Fischer, Gulzina Isakova and Ulan Termechikov: Do FX traders in Bishkek have similar perceptions to their London colleagues? Survey evidence of market practitioners' views 
2007-2 Ibrahim Chowdhury and Andreas Schabert: Federal Reserve Policy viewed through a Money Supply Lens

2007-3 Angelo Ranaldo: Segmentation and Time-of-Day Patterns in Foreign Exchange Markets

2007-4 Jürg M. Blum: Why ‘Basel II’ May Need a Leverage Ratio Restriction

2007-5 Samuel Reynard: Maintaining Low Inflation: Money, Interest Rates, and Policy Stance

2007-6 Rina Rosenblatt-Wisch: Loss Aversion in Aggregate Macroeconomic Time Series

2007-7 Martin Brown, Maria Rueda Maurer, Tamara Pak and Nurlanbek Tynaev: Banking Sector Reform and Interest Rates in Transition Economies: Bank-Level Evidence from Kyrgyzstan

2007-8 Hans-Jürg Büttler: An Orthogonal Polynomial Approach to Estimate the Term Structure of Interest Rates

2007-9 Raphael Auer: The Colonial Origins Of Comparative Development: Comment. A Solution to the Settler Mortality Debate

2007-10 Franziska Bignasca and Enzo Rossi: Applying the Hirose-Kamada filter to Swiss data: Output gap and exchange rate pass-through estimates

2007-11 Angelo Ranaldo and Enzo Rossi: The reaction of asset markets to Swiss National Bank communication

2007-12 Lukas Burkhard and Andreas M. Fischer: Communicating Policy Options at the Zero Bound

2007-13 Katrin Assenmacher-Wesche, Stefan Gerlach, and Toshitaka Sekine: Monetary Factors and Inflation in Japan

2007-14 Jean-Marc Natal and Nicolas Stoffels: Globalization, markups and the natural rate of interest

2007-15 Martin Brown, Tullio Jappelli and Marco Pagano: Information Sharing and Credit: Firm-Level Evidence from Transition Countries

2007-16 Andreas M. Fischer, Matthias Lutz and Manuel Wälti: Who Prices Locally? Survey Evidence of Swiss Exporters

2007-17 Angelo Ranaldo and Paul Söderlind: Safe Haven Currencies 
2008-1 Martin Brown and Christian Zehnder: The Emergence of Information Sharing in Credit Markets

2008-2 Yvan Lengwiler and Carlos Lenz: Intelligible Factors for the Yield Curve

2008-3 Katrin Assenmacher-Wesche and M. Hashem Pesaran: Forecasting the Swiss Economy Using VECX* Models: An Exercise in Forecast Combination Across Models and Observation Windows

2008-4 Maria Clara Rueda Maurer: Foreign bank entry, institutional development and credit access: firm-level evidence from 22 transition countries

2008-5 Marlene Amstad and Andreas M. Fischer: Are Weekly Inflation Forecasts Informative?

2008-6 Raphael Auer and Thomas Chaney: Cost Pass Through in a Competitive Model of Pricing-to-Market

2008-7 Martin Brown, Armin Falk and Ernst Fehr: Competition and Relational Contracts: The Role of Unemployment as a Disciplinary Device

2008-8 Raphael Auer: The Colonial and Geographic Origins of Comparative Development

2008-9 Andreas M. Fischer and Angelo Ranaldo: Does FOMC News Increase Global FX Trading?

2008-10 Charlotte Christiansen and Angelo Ranaldo: Extreme Coexceedances in New EU Member States' Stock Markets

2008-11 Barbara Rudolf and Mathias Zurlinden: Measuring capital stocks and capital services in Switzerland

2008-12 Philip Sauré: How to Use Industrial Policy to Sustain Trade Agreements

2008-13 Thomas Bolli and Mathias Zurlinden: Measuring growth of labour quality and the quality-adjusted unemployment rate in Switzerland

2008-14 Samuel Reynard: What Drives the Swiss Franc?

2008-15 Daniel Kaufmann: Price-Setting Behaviour in Switzerland - Evidence from CPI Micro Data

2008-16 Katrin Assenmacher-Wesche and Stefan Gerlach: Financial Structure and the Impact of Monetary Policy on Asset Prices

2008-17 Ernst Fehr, Martin Brown and Christian Zehnder: On Reputation: A Microfoundation of Contract Enforcement and Price Rigidity 
2008-18 Raphael Auer and Andreas M. Fischer: The Effect of Low-Wage Import Competition on U.S. Inflationary Pressure

2008-19 Christian Beer, Steven Ongena and Marcel Peter: Borrowing in Foreign Currency: Austrian Households as Carry Traders

2009-1 Thomas Bolli and Mathias Zurlinden: Measurement of labor quality growth caused by unobservable characteristics

2009-2 Martin Brown, Steven Ongena and Pinar Yeșin: Foreign Currency Borrowing by Small Firms

2009-3 Matteo Bonato, Massimiliano Caporin and Angelo Ranaldo: Forecasting realized (co)variances with a block structure Wishart autoregressive model

2009-4 Paul Söderlind: Inflation Risk Premia and Survey Evidence on Macroeconomic Uncertainty

2009-5 Christian Hott: Explaining House Price Fluctuations

2009-6 Sarah M. Lein and Eva Köberl: Capacity Utilisation, Constraints and Price Adjustments under the Microscope

2009-7 Philipp Haene and Andy Sturm: Optimal Central Counterparty Risk Management

2009-8 Christian Hott: Banks and Real Estate Prices

2009-9 Terhi Jokipii and Alistair Milne: Bank Capital Buffer and Risk Adjustment Decisions

2009-10 Philip Sauré: Bounded Love of Variety and Patterns of Trade

2009-11 Nicole Allenspach: Banking and Transparency: Is More Information Always Better?

2009-12 Philip Sauré and Hosny Zoabi: Effects of Trade on Female Labor Force Participation

2009-13 Barbara Rudolf and Mathias Zurlinden: Productivity and economic growth in Switzerland 1991-2005

2009-14 Sébastien Kraenzlin and Martin Schlegel: Bidding Behavior in the SNB's Repo Auctions

2009-15 Martin Schlegel and Sébastien Kraenzlin: Demand for Reserves and the Central Bank's Management of Interest Rates

2009-16 Carlos Lenz and Marcel Savioz: Monetary determinants of the Swiss franc 
2010-1 Charlotte Christiansen, Angelo Ranaldo and Paul Söderlind: The Time-Varying Systematic Risk of Carry Trade Strategies

2010-2 Daniel Kaufmann: The Timing of Price Changes and the Role of Heterogeneity

2010-3 Loriano Mancini, Angelo Ranaldo and Jan Wrampelmeyer: Liquidity in the Foreign Exchange Market: Measurement, Commonality, and Risk Premiums

2010-4 Samuel Reynard and Andreas Schabert: Modeling Monetary Policy

2010-5 Pierre Monnin and Terhi Jokipii: The Impact of Banking Sector Stability on the Real Economy

2010-6 Sébastien Kraenzlin and Thomas Nellen: Daytime is money

2010-7 Philip Sauré: Overreporting Oil Reserves

2010-8 Elizabeth Steiner: Estimating a stock-flow model for the Swiss housing market

2010-9 Martin Brown, Steven Ongena, Alexander Popov, and Pinar Yesin: Who Needs Credit and Who Gets Credit in Eastern Europe?

2010-10 Jean-Pierre Danthine and André Kurmann: The Business Cycle Implications of Reciprocity in Labor Relations

2010-11 Thomas Nitschka: Momentum in stock market returns: Implications for risk premia on foreign currencies 
Swiss National Bank Working Papers are also available at www.snb.ch, section Publications/Research Subscriptions or individual issues can be ordered at Swiss National Bank, Fraumünsterstrasse 8, CH-8022 Zurich, fax+41 4463181 14, E-mail library@snb.ch 